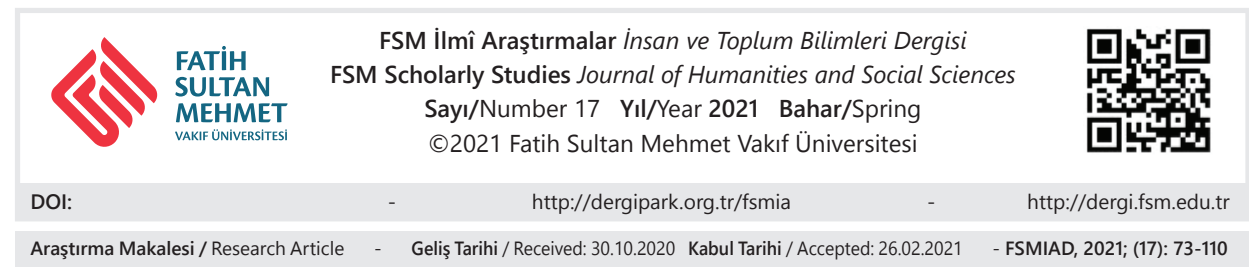

\title{
Süleymannâme (TSMK, H. 1517) Vr. 503a'da Yer Alan Elçi Kabul Sahnesinde Kozmik Merkez Üzerinden Yol Alan İktidar Dili*
}

Zaliha Peçe $\mathrm{e}^{*}$

$\ddot{\mathbf{O z}}$

Kitap sanatları arasında önemli bir yere sahip olan minyatür sanatı, yazma eserler içerisinde yer alan metinleri görselleştirmek amacı ile yapılmışlardır. Bir haminin desteği ile vücuda getirilen resimli tarihlerde eserin metninde olduğu gibi içerisinde yer alan minyatürlerde de hami lehine inşa edilmiş taltif edici bir dilin varlığı göze çarpar. Bu bağlamda bizzat padişahın ya da yüksek makamdaki devlet görevlilerinin emri ile yapımına başlanan resimli tarihlerde padişah lehine inşa edilen, onun iktidarını taltif edici bir görsel dilin varlığ dikkati çeker. Ele alınan makalede, padişahtan yana olan bu iktidar dilinin Osmanlı minyatürlerindeki varlığı, Türklerdeki iktidar sembolleri ve kozmik merkez kavramları üzerinden analiz edilmeye çalışılmıştır. Bu analizin yapılacağı örnek olarak ise bizzat padişahın talimatı ile yapımına başlanan 1558 tarihli Süleymannâme (TSMK, H. 1517) adlı eserin vr. 503a da yer alan “Kanunî Sultan Süleyman'in Halep'teki Sarayda Hicaz'dan Sorumlu Mekke Şerifi’nin Elçisini Huzura Kabulü” sahnesi seçilmiştir. Yapı-

\footnotetext{
* $\quad$ Bu çalışma, Fatih Sultan Mehmet Vakıf Üniversitesi Lisansüstü Eğitim Enstitüsü Geleneksel Türk Sanatları Anasanat Dalında sürdürülen "Osmanlı Minyatürlerinde Kanunî Sultan Süleyman İmgesi” isimli sanatta yeterlik tez çalışmasından türetilmiştir.

**: Sanatta Yeterlik Öğrencisi, Fatih Sultan Mehmet Vakıf Üniversitesi Lisansüstü Eğitim Enstitüsü, İstanbul/Türkiye, zalihapece@gmail.com, orcid.org/0000-0002-1573-2138.
} 
lan bu analiz sonucunda mevcut minyatürde merkez ve iktidar sembollerinin varlığından müteşekkil bir dikey kompozisyon şemasının varlığına rast gelinmiştir.

Anahtar Kelimeler: Süleymannâme, kozmoloji, kozmik merkez, iktidar sembolleri, minyatür.

\title{
Language of Power Through the Cosmic Center in the 'Receiving of the Messenger' Scene of the Suleiman-Nama (Süleymannâme) (TSMK, H. 1517) Vr. 503a
}

\begin{abstract}
Miniature art, which has an important place among the book arts, was created with the aim of visualizing the texts in the manuscripts. In the illustrated dates brought to life with the support of a patron, the presence of a gratifying language built in favor of the patron stands out in the miniatures included as well as in the text of work. In this context, the presence of a visual language built in favor of the sultan on the illustrated dates, which were started to be created by the order of the sultan himself or the state officials in high office, that gratifies his power, draws attention. In the article discussed, the existence of this language of power in Ottoman miniatures were tried to be analyzed through the concepts of symbols of power in Turks and the cosmic center. As the example through which this analysis was to be done, the scene "Suleiman the Magnificent Receiving the Messenger of the Sharif of Mecca Responsible of Hijaz in the Palace in Aleppo" in the vr. 503a of the 1558 dated work d Suleiman-nama (Süleymannâme) (TSMK, H. 1517), the making of which had started by the order of sultan, was selected. As a result of this analysis, a vertical composition scheme consisting of the symbols of center and power has been found in the present miniature.
\end{abstract}

Keywords: Süleymannâme, cosmology, cosmic center, symbols of power, miniature. 


\section{Giriş}

Saray içerisinde aktif dolaşım içerisinde olan, hanedan ve saray çevresi tarafından okunup bu çevrelerin eğitiminde etkin bir rol oynayan resimli tarihler, okuyucularının görüşlerini şekillendirmede, hamilerinin fikirlerini hedef kitle olan Osmanlı sarayı mensupları arasına yaymada önemli bir görev üstlenmişlerdir ${ }^{1}$. $\mathrm{Bu}$ sayede Osmanlı hanedanının ve yönetici elitinin timsalini inşa etmeye yardımcı olmuşlar, sarayın emperyal kimliğini oluşturarak, saray içerisindeki sosyal hiyerarşiyi meşrulaştırmada hatırı sayılır bir etki oluşturmuşlardır².

Çoğunlukla padişah, bürokratik-askeri sınıf ve kapıkullarının siparişi üzerine, onların hamiliğinde, politik bir savaşın silahı, bir propaganda aracı olarak siyasal amaçlarla vücuda getirilen resimli tarihler, hamilerinin iktidarını ve gücünü pekiştirmişlerdir ${ }^{3}$. Nitekim eserlerin metininde ve bu metine eşlik eden minyatürlerde hami lehine inşa edilmiş olan bir ikonografinin, bir iktidar dilinin varlığ 1 göze çarpar ${ }^{4}$. Sanatsal ve edebi söylem aracılığı ile iktidardan yana yaratılan bu dil Osmanlı sarayı da dâhil tarihte her daim rastlanıla gelen bir durum olmuştur ${ }^{5}$. Osmanlı Sarayının ideal dünya düzeni şeklinde sunulduğu bu eserlerde, eserlerin metin ve minyatürleri meşruiyet ve düzeni yansıtır bir mahiyet taşımışlardır ${ }^{6}$.

Resimli tarihlerde bahsi geçen iktidar dili, hamilerin kendi lehlerine olumlu bir imaj yaratmaları, kendilerini padişaha faydalı bir kul olarak göstermeleri gayeleri ile inşa edilmiştir? ${ }^{7}$ Böylece hamiler, saray hiyerarşilerindeki konumlarını sanat hamiliği ile etkilemeye çalışı kendilerine ve mensup oldukları camiaya dair belirli mesajları yaymak için yazmaların ifade potansiyelinden faydalanmış$\operatorname{lar}^{8}$ bu doğrultuda bir iktidar dili oluşturarak kendi lehlerine bir propaganda gerçekleştirmişlerdir.

Resimli tarihlerin propaganda potansiyelinden yararlanan, bu dili kendi lehinde kullanan ilk saraylı Sokullu Mehmed Paşa (d. 1505 - ö. 1579) olmuştur9. Bu güçlü sadrazam, III. Murad (sal. 1579-1595) döneminin ilk yıllarında sönen

1 Emine Fetvacı, Sarayın Imgeleri, İstanbul, Yapı Kredi Yayınları, 2013, s. 46, 47.

2 a.e., s. 40, 43, 46, 48, 137.

3 a.e., s. 19, 26,140; Tülin Değirmenci, İktidar Oyunlarl ve Resimli Kitaplar II. Osman Devrinde Değişen Güç Simgeleri, İstanbul, Kitap Yayınevi, 2012, s. 16.

4 Tülin Değirmenci, a.g.e., s. 17.

5 Emine Fetvac1, a.g.e., s. 44.

6 a.e., s. $119,137$.

7 a.e., s. 19.

8 a.e., s. $20,138$.

9 a.e., s. 42. 
siyasal ikbalini, hamisi olduğu resimli tarihlerde kendisi hakkında olumlu intiba yaratarak düzeltmeye çalışmıştır ${ }^{10}$. Sonraki dönemlerde sultanın savaş sahasından saraya çekilmesi ile birlikte değişen güç dengeleri, sarayı yeni güç merkezi haline getirmiş, bunun sonucu olarak hadımağaların rolleri ve saraydaki güçleri $\operatorname{artmıştır~}^{11}$. Hadımağalar sahip oldukları bu yeni konumları ile yazma eser hamiliğinde etkin bir rol alarak bu eserler vasıtası ile saray içerisindeki konumlarını pekiştirmişlerdir.

Sokullu Mehmed Paşa'nın ardından Dârüssaâde Ağası Mehmed Ağa (d.? - ö. 1590), Bâbüssaâde Ağası Gazanfer Ağa (d. ? - ö. 1603), Darüssaâde Ağası elHac Mustafa Ağa (d. ? - ö. 1624) ve Darüssaâde Ağası Süleyman Ağa (d.? - ö. 1622) gibi hadımağalar da resimli tarih hamileri olarak kendi konumlarını güçlendirmek, saray içerisinde artan etkin konumlarını pekiştirmek amacı ile sanatsal eser siparişlerinin gücünden etkin bir şekilde yararlanmışlar, hamisi oldukları eserlerin gerek metinlerinde, gerekse minyatürlerinde kendi lehlerine bir dil inşa ettirmişlerdir ${ }^{12}$.

III. Murad döneminde, Dârüssaâde Ağası Mehmed Ağa'nın hamiliğinde yazılmış olan Şehinşahnâme I (İ̈K, F. 1404) adlı eserde, Mehmed Ağa'nın betimlenme biçimi, ağanın saray içerisindeki artan gücünü ve saray içerisindeki değişen güç dengelerini gözler önüne serer ${ }^{13}$. Sultan için hazırlanan bir eser içerisinde Dârüssaâde Ağası Mehmed Ağa'nın peş peşe 4 minyatürde resmedilmiş olması, ağanın bu minyatürlerde Sadrazam Sokullu Mehmed Paşa'nın uğradığ suikastı soruşturan güçlü bir karakter olarak karşımıza çıkması, saray içerisinde hadımağalar lehine değişen güç dengelerini yansıtması14 açısından mevcut eserdeki hami lehine inşa edilmiş iktidar dilini gözler önüne serer. Osmanlı minyatürlerinde genellikle kapı eşiğinde, pencereden bakarken ya da emir bekler durumda elleri önlerinde bağlı, edilgen bir duruşla resmedilen hadımağa figürünün aksine15 bu eserde Mehmed Ağa, sahip olduğu güçlü ikonografi ile adeta bir baş aktör gibi sunulmuştur. Bu bağlamda Mehmed Ağa'nın bir hadımağa için oldukça sıra dışı denecek bir şeklide at üzerinde, buyurgan bir eda ile gösterildiği aynı eserin vr. 131b'de yer alan minyatürü, resimli tarihlerde hami lehine inşa edilmiş olan görsel dilin varlığına güzel bir örnek teşkil eder (bkz. R. 1).

10 a.e., s. 70.

11 Tülin Değirmenci, a.g.e., s. 37, 38.

12 Emine Fetvac1, a.g.e., s. 42, 43, 137; Tülin Değirmenci, a.g.e., s. 41, 43.

13 Emine Fetvac1, a.g.e., s. 200; Tülin Değirmenci, a.g.e., s. 43.

14 Tülin Değirmenci, a.g.e., s. 43, 44; Emine Fetvac1, a.g.e., s. 203

15 Emine Fetvac1, a.g.e., s. 204, 205. 


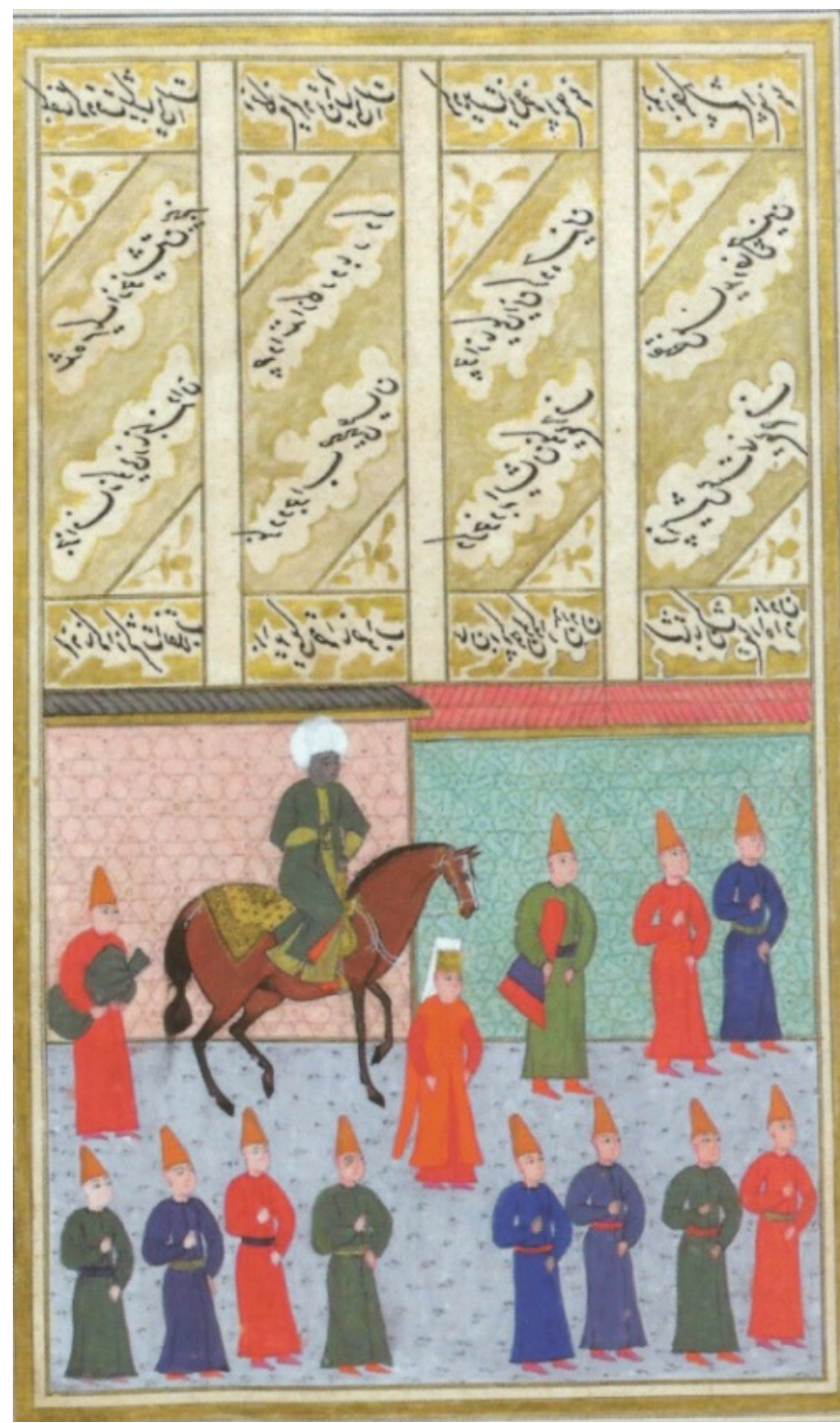

R. 1- Darüssaade Ağası Mehmed Ağa Sokulluyu ölüm döşeğinde görmeye giderken, Şehinşahnâme I, 1581, İÜK, F. 1404, vr. 131b (Emine Fetvac1, Sarayın Imgeleri, İstanbul, Yap1 Kredi Yayınlar1, 2013, s. 202, Resim 4.02).

Osmanlı Sarayını ideal dünya düzeni şeklinde sunan resimli tarihler yönetici elitin olduğu kadar padişahın ve Osmanlı hanedanının de ideal kamusal timsalini şekillendirmişler, bu timsalin ilgili çevrelere tanıtılmasına katkıda bulunmuşlardır ${ }^{16}$. 
Esrelerin gerek metinlerinde gerekse minyatürlerinde ideal padişah imgesi oluşturulmaya çalışılmış, padişahtan, hanedan ve saraydan medhile bahseden metinlere, imparatorluğun ve geleneklerinin ağırlığını gözler önüne seren, padişaha ve saraya ait ideal kamusal timsalin yer aldığı minyatürler eşlik etmiştir ${ }^{17}$. Bu minyatürlerde sarayın ihtişamını yansıtır şekilde kurgulanmış kompozisyon düzenleri, Osmanlı saray portresini oturtmaya yönelik tekrarlı kompozisyonlar, merkezi konuma yerleştirilmiş padişah figürü ve ikonik tasvirler sarayın gücüne, değişmez düzenine ve hanedanın sürekliliğine gönderme yaparak ideal padişah imgesini tesis etmeye çalışmışlardır ${ }^{18}$.

Osmanlı hanedan tarihine 12 Osmanlı padişahının eşlik ettiği 1579 tarihli Klyafetü'l-İnsaniyye fì Şemâili'l-Osmâniyye (TSM, H. 1563)'de yer alan padişah portre serisi, resimli tarihlerde inşa edilmeye çalışlan ideal padişah imgesinin önemli örneklerinden birini teşkil eder (bkz. R. 2). Hükümdarın soy çizgisine vurgu yaparak Osmanlı hanedanının meşruiyetini Allah tarafından seçilmiş olmasına bağlayan eser, Türklerdeki kozmik kurguya atıf yapan mekân kurgusu, tekrarlı mekân anlayışı ve iktidar sembollerinden müteşekkil figür anlayışı ile Osmanlı padişahları için ideal bir kurumsal kimlik yaratarak ${ }^{19}$ iktidardan yana bir görsel iktidar dili tesis eder.
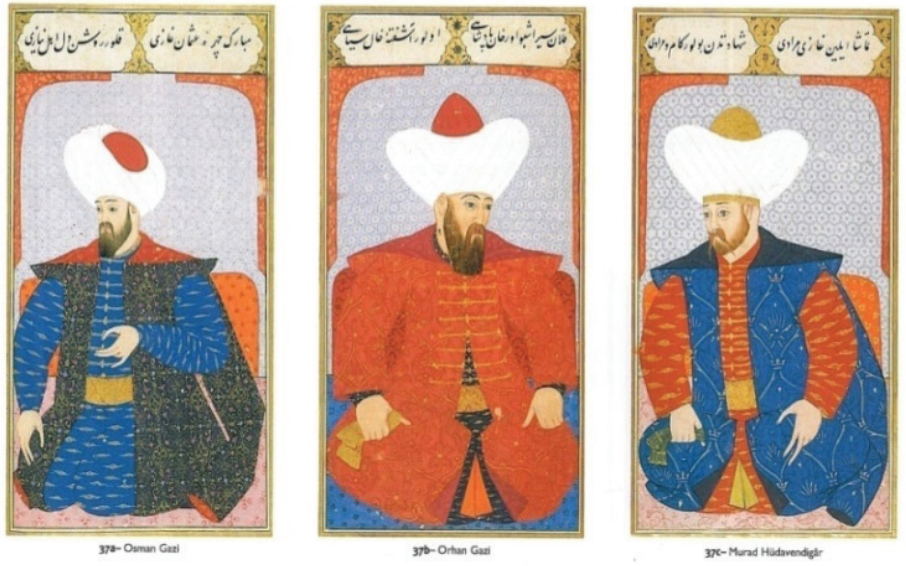

17 a.e., s. 20, 24, 26, 331.

18 Emine Fetvacı, a.g.e., s. 133; Zaliha Peçe, "Nakkaş Osman ve Levnî’ye Ait Padişah Portrelerinin Kompozisyon ve Teknik Açıdan Karşılaştırılması”, (Yayımlanmamış Yüksek Lisans Tezi), Fatih Sultan Mehmet Vakıf Üniversitesi Güzel Sanatlar Enstitüsü Geleneksel Türk Sanatları Ana Sanat Dal1, İstanbul, 2015, s. 63.

19 Emine Fetvac1, a.g.e., s. 190; Zaliha Erdoğan Peçe, “Nakkaş Osman'ın Padişah Portrelerinde Görülen Kozmik Kurgu ve İktidarı Taltif Edici Unsurlar, Levnî’nin Bu Kalıba Getirmiş Olduğu Yenilikler”, Lale Kültür Sanat ve Medeniyet Dergisi, sa. 2, İstanbul, 2020, s. 86, 87, 88. 

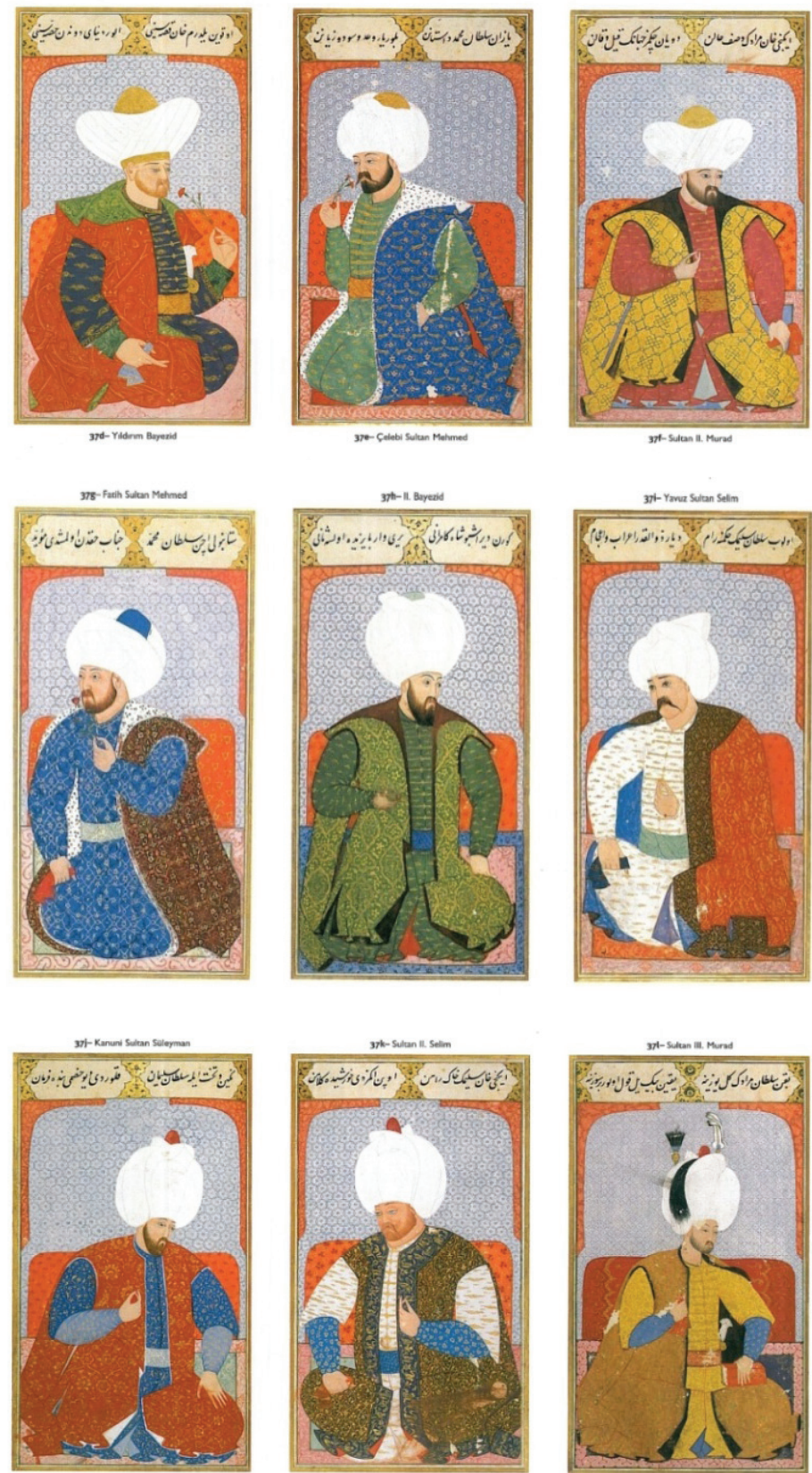

R. 2- Klyafetü'l-İnsaniyye fî Şemâili 'l-Osmâniyye, 1579, TSMK, H. 1563 (Filiz Çağman, "Osmanlı Sarayının Yorumu: Üstad Osman ve Dizisi”, Padişahın Portresi Tesavir-i Âl-i Osman, İstanbul, Türkiye İş Bankası, 2000, s. 166-167). 
Sarayın padişahla olan ilişkisine yön veren resimli tarihlerde, farklı dönemler içerisinde değişen ideal hükümdarlık anlayışına paralel olarak hükümdar tasvirinin de değişmiş olduğu görülür ${ }^{20}$. Örneğin hükümdarlık telakkisinin adil hükümdar kavramı üzerinde temellendirildiği bir dönemde yapılmış olan 1558 tarihli Süleymannâme (TSMK, H. 1517)'de askeri yönetimle adalet dağıtan adil hükümdar imgesinin altı çizilirken, 1587-89 tarihli Hünernâme II (TSMK, H. 1524)'de ise padişah, dönemin hükümdarlık telakkisine paralel olarak tasavvuftaki kâmil insan anlayışının bir timsali olarak, peygamberin varisi halife-sultan imaj $1^{21}$ ile resmedilmiştir.

Yukarıda verilmiş olan bilgiler, Osmanlı minyatürlerinde iktidardan yana olan görsel dilin inşasında, nakkaşların sahip oldukları bilgi birikimlerinin önemli bir rol oynadığını düşündürtür. Zira bu minyatürlerin görsel diline dair arkeolojik bir kazı yapıldığında Osmanlı nakkaşlarının geçmişten kendi dönemine değin aktarıla gelen Türk kültürel mirasının kodlarına, Türk kozmoloji inancına ve iktidar sembollerine vakıf oldukları, kompozisyon kurgusunda, mekânın tasarımında, sahne içerisine yerleştirilen her bir unsurda ve dahi tercih edilen renklerde bu bilgilerden istifade ederek iktidardan yana bir dil inşa ettikleri görülür. Bu iktidar dilinin kimi zaman gök, yer ve yer altı birlikteliğinden, evrenin merkezinde bu üçünü birleştirdiğine inanılan bir gök direğinden (Kutup Yıldızı) müteşekkil kozmik evren anlayışı üzerinden de inşa ediliyor olabileceği fikri akla gelmektedir. $\mathrm{Bu}$ ana iskelet üzerine eklemlenen çeşitli iktidar sembollerinin ise mevcut dilin kuvvetlendirilmesi amacı ile kompozisyona içerisine yerleştirilmiş destekleyici unsurlar olabileceği düşünülmektedir.

$\mathrm{Bu}$ taltif edici dil, konu itibari ile doğrudan iktidarı ela alan, onun gücünü göze getirerek görünür k1lan Şehnâme, Sûnâme, Gazavatnâme ve Silsilenâme gibi yazma türlerinde yoğun bir şekilde hissedilir. Bu yazma türleri padişahın güç ve kudretini sergiledikleri cülus, elçi kabul, av, savaş ve düğün şöleni gibi sahneleri ele almaları itibari ile iktidarı yüceltici bir araç olma görevini üstlenirler. Nitekim av, savaş ve cülus sahnelerini konu edinen tasvirler, Yakındoğu'da emperyal ikonografinin tarihi boyunca varlığını sürdüren dört kraliyet mecazı olmuşlardır ${ }^{22}$. Yine hanedan soyunu büyük din ve tarih büyüklerine ve dahi Hz. Âdem'e bağlayarak kesintisiz hanedan zinciri oluşturma niyeti ile yapilan Silsilenâmeler de hanedanın sürekliliğine ve gücüne yaptığı vurgu ile iktidarı yüceltici bir alanın içerisine dâhil olurlar.

20 Tülin Değirmenci, a.g.e., s. 15; Emine Fetvac1, a.g.e., s. 21, 43, 330, 331.

21 Emine Fetvac1, a.g.e., s. 73, 179, 337, 340.

22 a.e., Dipnot 56, s. 37. 
Ârifî mahlaslı saray şehnâmecisi Fethullah Çelebi'nin (d.?- ö. 1562) Osmanlı tarihini konu edinen Şehnâme-i Âl-i Osman adlı beş ciltlik eserinin son cildi olan Süleymannâme (TSMK, H. 1517), Osmanlı padişahları arasında en güçlü iktidar figürlerinden biri olan Kanunî Sultan Süleyman'ın (sal. 1520-1566) sağlığında, onun himayesinde yazılmış ${ }^{23}$ ilk resimli tarih kitabıdır. Eser, sultanın saltanatının 1520-1555 yılları arasındaki olayları konu edinir ${ }^{24}$. Çalışmanın metnine Doğulu ve Batılı sanatkârlar tarafından yapılmış 4'ü çift sayfa olmak üzere 69 adet minyatür eşlik eder ${ }^{25}$.

Süleymannâme Osmanlı şehnâmelerinin prototipini oluşturmuş olması itibari $^{26}$ ile Osmanlı şehnâmeleri arasında ayrıcalıklı bir yere sahiptir. Nitekim Osmanlı klâsik minyatür üslubunun birçok ana kompozisyon şemaları ilk defa bu eser içerisinde yer alan minyatürlerde ortaya çıkmıştır ${ }^{27}$. Eser sahip olduğu tüm bu özellikleri ile gerek metni gerekse içerisinde yer alan minyatürleri ile bize göre üzerinde iktidar dilinin yoğun bir şekilde müşahede edilebileceği en ideal örneklerden birini teşkil eder.

Bu doğrultuda Süleymannâme (TSMK, H. 1517) vr. 503a'da yer alan "Kanunî Sultan Süleyman'ın Halep’teki Sarayda Hicaz'dan Sorumlu Mekke Şerifi'nin Elçisini Huzura Kabulü" sahnesinde kozmik merkez üzerinden yol alan bir iktidar dilinin varlığını konu edinen bu makale, Osmanlı minyatürlerinde bahsi geçen iktidar dilinin varlığını, bu dilin nasıl bir yöntem takip edilmek suretiyle görsel bir forma dönüştürülmüş olduğunu tespit etmeyi amaçlamaktadır.

Çalışmada, bahsi geçen iktidar dilinin varlığı Türklerdeki yer ve gök birlikteliğinden oluşan dikey kurgulu kozmik evren ve kozmik merkez kavramları üzerinden irdelenmeye çalışılacaktır. Bu minvalde üzerinde arzu edilen amaca

23 Banu Mahir, Osmanlı Minyatür Sanatı, İstanbul, Kabalc1, 2012, s. 56; Esin Atıl, “Arifî’nin Süleymannâmesi'nde Kanunî’nin Seferleri”, P Dünya Sanatı Dergisi, sa. 30, İstanbul, 2003, s. 78; Reha Günay, "Süleymannâme Minyatürlerinde Mekân ve Anlatım Teknikleri“, Topkapı Sarayı Müzesi Yıllık 5, İstanbul, 1992, s. 57.

24 Serpil Bağc1-Filiz Çağman-Günsel Renda-Zeren Tanındı, Osmanlı Resim Sanatı, İstanbul, T. C. Kültür ve Turizm Bakanlığı, 2006, s. 100.

25 Esin Atıl, a.g.m., s. 69; Fatma Sinem Eryılmaz Arenas Vives, "The Shehcis of Sultan Süleyman: Arif and Eflatun and Their Dynastic Project", (Sanal Ortamda Ulaşıma Açık Doktora Tezi), University of Chicago, Chicago, 2010, s. 166.

26 Zeren Akalay, “Tarihi Konularda Türk Minyatürleri”, Sanat Tarihi Yıllı̆̆ 1969-1970, İstanbul, İstanbul Üniversitesi Edebiyat Fakültesi Sanat Tarihi Enstitüsü, 1970, s. 151.

27 a.e., s. 161; Nurhan Atasoy, "1558 tarihli Süleymannâme ve Macar Nakkaş Pervane", Sanat Tarihi Ylllı̆̆ 1969-1970, İstanbul, İstanbul Üniversitesi Edebiyat Fakültesi Sanat Tarihi Enstitüsü, 1970, s. 167, Esin At1l, a.g.m., s. 69. 
yönelik analizlerin yapılabileceği en ideal minyatür örneğinin tespiti yoluna gidilmiş, Süleymannâme (TSMK, H. 1517)'ye dair yukarıda verilmiş olan bilgiler göz önünde bulundurulduğunda bu örneğin bahsi geçen eser içerisinden seçilmesinin uygun olacağına kanaat getirilmiştir. Eser içerisinde, Emel Esin

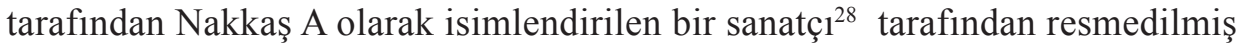
olduğu düşünülen vr. 503a'da ki elçi kabul sahnesi üzerinde bahsi geçen çalışmanın yapılacağ konu, gerekse "yer-gök" birlikteliğini ve "merkez" kavramını çağrıştıran dikey kompozisyon şeması (kozmik kurgu), bu şemayı anlamca destekleyen iktidar sembollerinin varlığı ile üzerinde iktidar dilinin rahatlıkla okunabileceği bir örnektir (bkz. R. 3; Ç. 1).

Kozmik kurgu ve kozmik merkez üzerinden yol alan bir görsel iktidar dilinin izinin sürülmeye çalışılacağı bu makalede analizi yapılacak olan minyatürün konusu hakkında verilen bilginin ardından ilgili minyatürde bahsini etmiş olduğumuz görsel dilin varlığ dikey kurgulu kompozisyon şeması ve bu şema üzerinde yer alan iktidar sembolleri üzerinden tespit edilmeye çalışılacaktır.

28 Esin At1l, Süleyman The Illustrated History of Süleyman the Magnificent, New York, Harry and Abrams Inc., 1986, s. 66. 


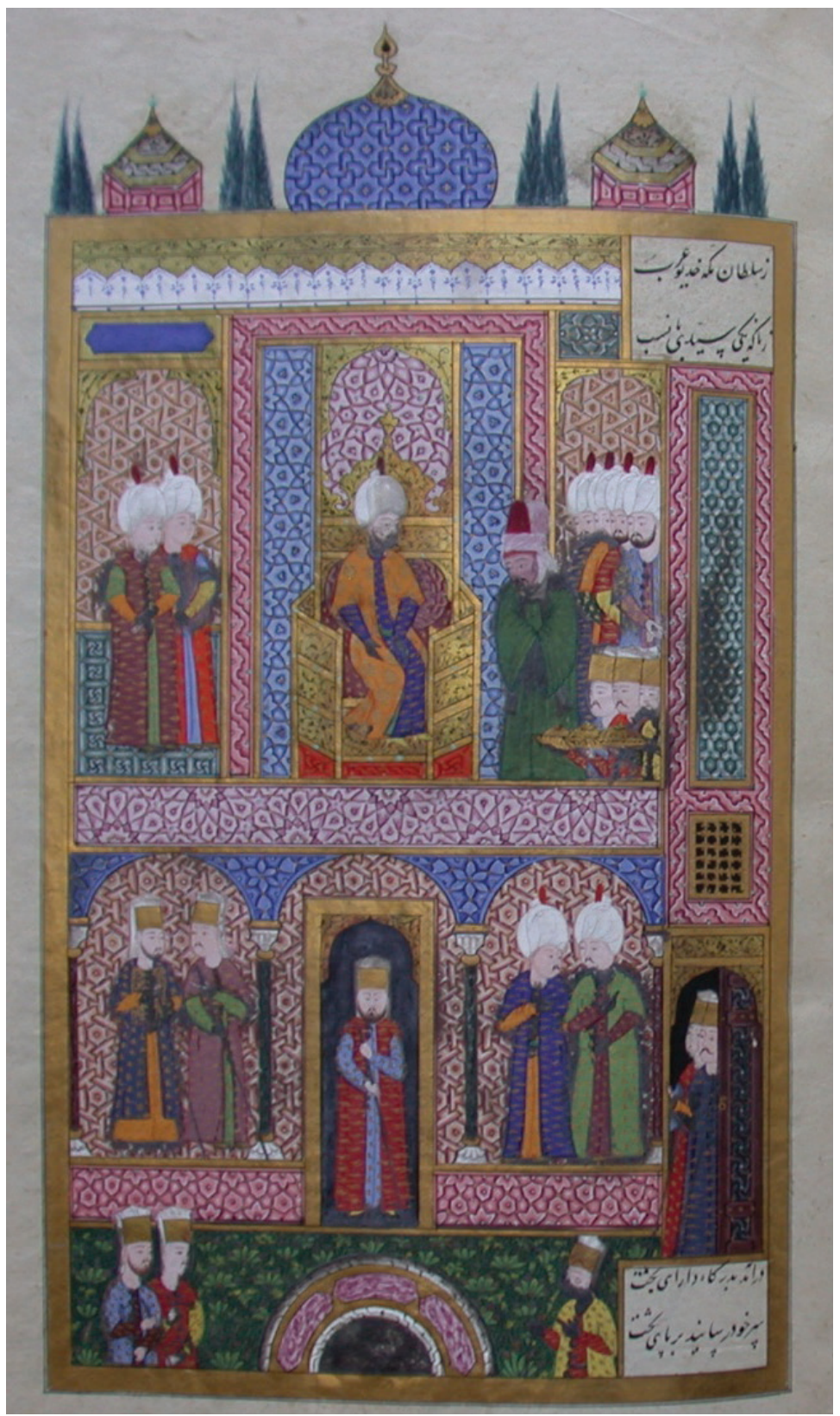

R. 3- Kanunî Sultan Süleyman'1n Halep'teki sarayda Hicaz'dan sorumlu Mekke şerifinin elçisini huzura kabulü, Süleymannâme, 1558, TSMK, H. 1517, vr. 503a (Esin At1l, Süleymannâme The Illustrated History of Süleyman the Magnificent, New York, Harry and Abrams Inc., 1986, s. 200). 


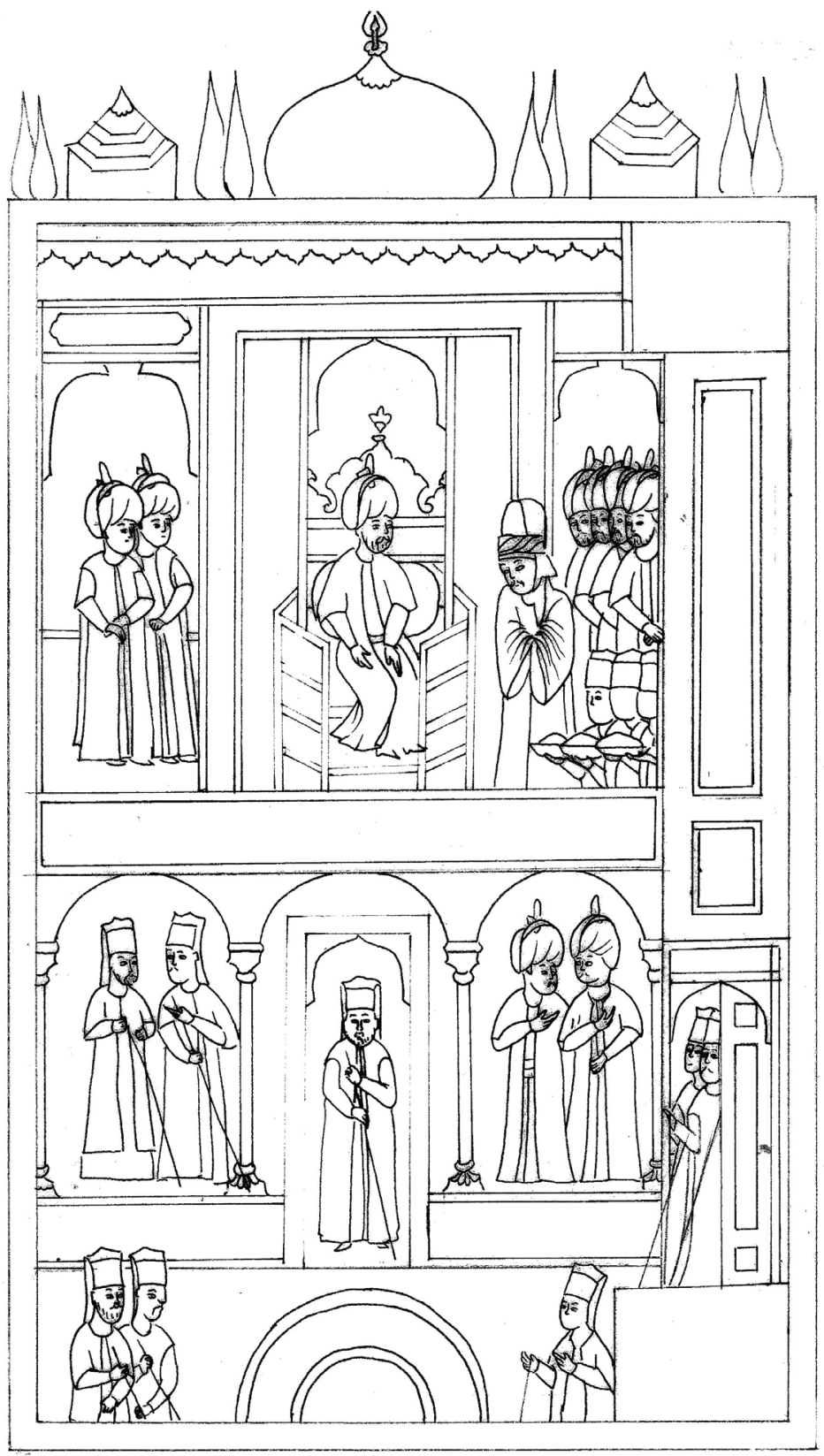

Ç. 1 


\section{Minyatürün Konusu}

Kanunî Sultan Süleyman 1548-1549 yılında 2. İran Seferi'ne çıkmıştır²'. Padişah bu sefer sırasında kışı geçirmek üzere 25 Kasım 1548 Pazar günü Halep'e geçmiş, 6 ay 10 gün burada kaldıktan sonra 6 Haziran 1549 Perşembe günü Diyarbakır'a gitmek üzere orduyu hümâyûn ile birlikte Halep'ten ayrılmıştır ${ }^{30}$.

Misır'in 1517 yılında Yavuz Sultan Selim (sal. 1512-1520) tarafindan fethinin ardından Hicaz, kutsal şehirleri Mekke ve Medine ile birlikte kendi isteği ile Osmanlı himayesi altına girmiştir ${ }^{31}$. Hicaz emiri Osmanlı sultanına olan bağl1lığını bir kez daha göstermek amacı ile Kanunî Sultan Süleyman'ın Halep’te bulunduğu süre içerisinde kendisine bir elçi göndermiştir ${ }^{32}$. Süleymannâme'nin metnine göre bu ziyaret 1548-1549 yılının kışında vuku bulmuştur ${ }^{33}$.

Hicaz büyükelçisinin Hicaz emiri adına gerçekleştirmiş olduğu bu ziyaretin hemen ardından Kanunî, Şii baskınına karşı padişahtan yardım isteyen bir başka Müslüman yönetici Moğol Hükümdarı Cengiz Han'ın (d. 1162- ö. 1227) torunu Taşkent (Özbek) emirinin göndermiş olduğu elçiyi huzura kabul etmiştir ${ }^{34}$.

Esin At1l, Kanunî Sultan Süleyman'ın, bir başka Müslüman hükümdar olan İran şahı ile olan savaşının hâlihazırda devam ettiği bir süreç içerisinde bahsi geçen Müslüman hükümdarların Kanunî Sultan Süleyman'a olan bağl1l1k yeminlerinin bir parçası olarak gerçekleştirmiş oldukları bu elçi ziyaretlerinin oldukça önemli ve manidar olduğunu belirtir ${ }^{35}$. Bu durum Osmanlı sultanının Safeviler karşısında giriştikleri mücadelede diğer Müslüman liderlerinin kendilerini desteklediklerini ve yapmış oldukları bağlılık yeminleri ile birlikte Osmanlı sultanını tüm Müslümanlar'ın lideri olarak görüp, desteklediklerini gözler önüne serer. $\mathrm{Bu}$ durum incelemiş olduğumuz minyatürde iktidardan yana olan görsel dilin varlık sebebini gerekçelendiren bir mahiyet taşır.

29 İsmail Hakk1 Uzunçarş1l1, Osmanlı Tarihi, İstanbul'un Fethinden Kanunî Sultan Süleyman'ın Ölümüne Kadar, c. 2, Ankara, Türk Tarih Kurumu, 2016, s. 359; Y1lmaz Öztuna, Kanunî Sultan Süleyman, İstanbul, Ötüken, 2016, s. 132; Tayyib Gökbilgin, Kanunî Sultan Süleyman, İstanbul, Kronik, 2019, s. 95.

30 İsmail Hakkı Uzunçarş11, a.g.e., s. 360; Y1lmaz Öztuna, a.g.e., s. 133; Turgut Güler, Demir Kuşaklı Cihângir Süleymannâme, İstanbul, Ötüken, 2016, s. 483, 485.

31 İsmail Hakk1 Uzunçarş1l1, a.g.e., s. 292; Esin Atıl, a.g.e., s. 201.

32 Esin At1l, a.g.e.,s. 201.

33 a.y.

34 a.y.

35 a.y. 


\section{Minyatürün Kozmik Kurgu ve Kozmik Merkez Açısından Analizi}

Elçi kabul sahnesinin resmedildiği bu minyatür ele aldığı konu itibari ile daha en başından iktidar vurgusu yapar. Zira daha önce de belirtilmiş olduğu gibi cülus, sünnet şölenleri, geçit alayları, av tertipleri ve elçi kabulleri gibi seremoniler padişahların gerek tebasına gerekse dünyaya kendi kudret ve güçlerini sergiledikleri sahalardır. İncelenmekte olan minyatürde ele alınan konunun yapmış olduğu iktidar vurgusunun, kompozisyonda iktidar lehine inşa edilmeye çalış1lan bir görsel dilin tesisi sureti ile de desteklenmeye çalış1lmış olduğu fark edilir. Bu görsel dilin, nakkaş tarafından bilinçli olarak yapılıp yapılmadığını kesin olarak bilemediğimiz, Türklerdeki dikey katmanlı evren, Kutup Yıldızı ve kozmik merkez kavramları üzerinden yol aldığı düşünülmektedir. Bahsi geçen kozmik kurguyu analiz edebilmek adına öncelikli olarak Türk kozmolojisindeki dikey katmanlı evren ve kozmik merkez kavramları hakkında bilgi verilmesi sonrasında ise ilgili kavramların mevcut minyatür üzerindeki görsel izdüşümlerinin tespit edilmesi gerekmektedir.

Türk kozmolojisinde evrenin "yer" ve "gök”ten müteşekkil bir unsur olduğu görüşü hâkimdir ${ }^{36}$. Bu "yer-gök" ikilisinde "yer" olarak belirtilen kısım va$\tan$ (vatan toprağı) kavramına tekabül eden kutsal "yer-su" (yer-sub) ikilisinden meydana gelmekte ve bu ikilinin ise birlikte gögü tamamladığına inanılmaktadır ${ }^{37}$. Uygurlular bu ikiliye "yer altı dünyasını" da dâhil etmişler böylece "yer" ve "gök”ten oluşan ikili evren anlayışı Uygurlarla birlikte "gök", "yer" ve "yer altı"ndan oluşan üçlü evren anlayışına dönüşmüştür ${ }^{38}$. "Su” unsuru üçlü evren anlayışında da kendine yer edinmiş bu minvalde "yer altı suları" yer altı katmanı ile bağlantılı bir unsur olarak görülmüsşür.

Türklerdeki üçlü evren anlayışında "yer-su" ikilisi bir hâkimiyet sembolü olup Türk kağanının Türk'ün yer ve suyunun sahibi olduğ $\mathrm{u}^{39}$ inancı benimsenmiştir. Bu inanca paralel olarak, Türk kağanın, "yer" ve "su” sahipsiz kal-

36 Bahaeddin Ögel, Türk Mitolojisi, c. 2, Ankara, Türk Tarih Kurumu, 2014, s. 187, 188; Talat Tekin, Orhon Yazıtları, Kül Tigin, Bilge Kağan, Tunyukuk, Ankara, BilgeSu, 2017, s. 37; Ekrem Memiş, Türk Kültür Tarihi (Türk Kültüründen Bazı Kesitler), Bursa, Ekim, 2015, s. 63; Mehmed Niyazi, Türk Devlet Felsefesi, İstanbul, Ötüken, 2017, s. 172.

37 Bahaeddin Ögel, a.g.e., s. 188, 409, 417, 418; Bahaeddin Ögel, Türklerde Devlet Anlayışı, İstanbul, Ötüken, 2016, s. 57, 163; Fuzuli Bayat, Türk Mitolojik Sistemi 2, İstanbul, Ötüken, 2015, s. 40; İsmail Taş, Türk Düşüncesinde Kozmogeni Kozmoloji, Konya, Kömen, 2011, s. 72 , 74, 118.

38 İsmail Taş, a.g.e., s. 230, 231.

39 Fuzuli Bayat, Türk Mitolojik Sistemi 1, İstanbul, Ötüken, 2015, s. 56; Bahattin Ögel, Türk Mitolojisi, c. 2, s. 459. 
masın diye, "gök”te Tanrının, "yer"de ise vatan toprağını oluşturan "yer" ve "suyun" (yer ve su ruhlarının) yardımı ile bu ikisinin arasında tahtında oturduğuna inanılmıştır ${ }^{40}$. Hükümdar bulunduğu bu konumda Gök-Tanrı tarafından bütün insanlığın üzerine hükümdar olarak oturtulmuş, Gök Tanrı'dan aldığı kut hasebiyle onun mümessili sayılmıştır"1. Sultanın "yerin ve göğün hükümdarı" olarak oturduğu bu konumu, "yerin ve gögün hükümdarı" imgesinin altını çizer gibi görünmektedir.

Hükümdarın yer ve gök arasındaki dikey konumuna eski Türk kaynaklarında da değinilir. Örneğin Türklerde "üzerine oturmak", yani "halkın üzerine hakan olarak oturmak", hakan ile halk arasında, yüce devlet ile millet arasında, dikeyine bir yükseklik ve mesafe anlayışını doğurur ${ }^{42}$. Nitekim Göktürk Yazıtları, Kültigin Kitabesinde yer alan: "Üstte mavi gök, yerde yă̆ız yer yaratıldı̆̆ında, ikisinin arasında insanoğulları yaratılmış. Insanoğullarının üzerine de atalarım, dedelerim Bumin Hakan ve Istemi Hakan hükümdar olarak tahta oturmuş "»3 ibareleri halk ve hakan arasındaki dikey hareketi gözler önüne serer. Görüldüğ̈̈ üzere Türklerde yücelik ve yükseklik, han tahtı ile özdeşleşen, onu tanımlayan kavramlar olmuştur ${ }^{44}$.

Yer ve gök unsurlarının birer hâkimiyet sembolü oluşu, hükümdarın yerin ve göğün desteği ile bu ikisi arasındaki konumu, Osmanlılar tarafindan da kabul görmüştür. Nitekim su ve nehir gibi unsurlar, Osmanlı padişahlarının "karaların ve denizlerin sultanı" olduğunu vurgulayan bir hâkimiyet sembolü olarak kullanılmışlar, "karaların ve denizlerin hâkimi", "kara ve denizlerin halifesi (yer-su)" gibi ifadeler, Osmanlı sultanları için kullanılan unvanlar arasında yer almıştır ${ }^{45}$.

40 Mehmed Niyazi, a.g.e., s. 36, 170, 172; Talat Tekin, a.g.e., s. 5, 37, 59, 63; Bahattin Ögel, Türk Mitolojisi, c. 1, Ankara, Türk Tarih Kurumu, 2014, s. 305, 306; Bahattin Ögel, Türk Mitolojisi, c. 2, s. 185, 417, 418; Bahattin Ögel, Türklerde Devlet Anlayışı, s. 31, 36, 44, 45, 57; Cengiz Balc1, Destanlar, Kitabeler ve Kutadgu-Bilig'den Örneklemelerle Türk Devlet Töresi, İstanbul, Bilgeoğuz, 2018, s. 47; Ekrem Memiş, a.g.e., s. 63.

41 Mehmed Niyazi, a.g.e., s. 170; Cengiz Balc1, s. 47; İsmail Taş, a.g.e., s. 159.

42 Bahattin Ögel, Türklerde Devlet Anlayışı, s. 94.

43 İsmail Taş, a.g.e., s. 42; Ögel, a.g.e., s. 94.

44 Bahattin Ögel, a.g.e., s. 94.

45 Mustafa Sabri Küçükaşçı, “Topkapı Sarayı'nda Kutsiyet ve Kutsal Mekânlar”, Topkapı Sarayı'nı Anlatmak, İstanbul, Kültür ve Turizm Bakanlığı, 2018, s. 173; Namık Sinan Turan, Hilâfet Erken İslâm Tarihinden Osmanlı'nın Son Yüzyılına, İstanbul, İstanbul Bilgi Üniversitesi Yayınları, 2017, s. 226; Vasilij Vladimiroviç Barthold, İslam'da İktidarın Serüveni Halife ve Sultan, İstanbul, Yeditepe, 2012, s. 114. 
$\mathrm{Bu}$ bilgiler eşliğinde incelenecek olan minyatüre bakıldığında hükümdarın "yer" ve "gök" arasındaki dikey konumuna atıf yapan bir kompozisyon kurgusunun varlığ dikkati çeker. Bu kurgu, padişahın mavi bir kubbe ile dairevi bir havuz arasında, bu ikisi ile aynı dikey hat üzerinde konumlanmış olması üzerinden yol alıyor gibi görünmektedir (bkz. Ç. 2). Bu şemanın daha sonraki dönemlerde yapılmış olan minyatürlerde de kullanılmış olduğu görülür (bkz. R. 4, R. 5) ${ }^{46}$. Bu görsel dili anlayabilmek için Türklerde mavi kubbe ve havuz unsurlarının sahip oldukları sembolik anlamlara değinmek gerekmektedir.

46 Matali'ü's-sa'âde ve Yenabi'ü's-siyâde, PBNF, Turc 242, vr. 7b, Hüner I, TSMK, H. 1523, vr. 57b,75b, 68b, 72a, 75b, 112b, 132b, 153b, Zübdetü't-tevârih, TSMK, H. 1321, vr. 33a, 43a, Hüner II, TSMK, H. 1524, 148a, Şemâil-i Âl-i Osmân TSMK, A.3592, vr.79a, Tarih-i Feth-i Yemen, İ̈K, T. 6045, 1594, vr. 7b, Gencine-i Feth-i Gence, TSMK, R. 1296, vr. 8b, Tercüme-i Şehnâme, NYPL, Spencer Turk, ms. 1'de yer alan minyatürlerin de benzer bir kompozisyon kurgusuna sahip olduğu görülür. 


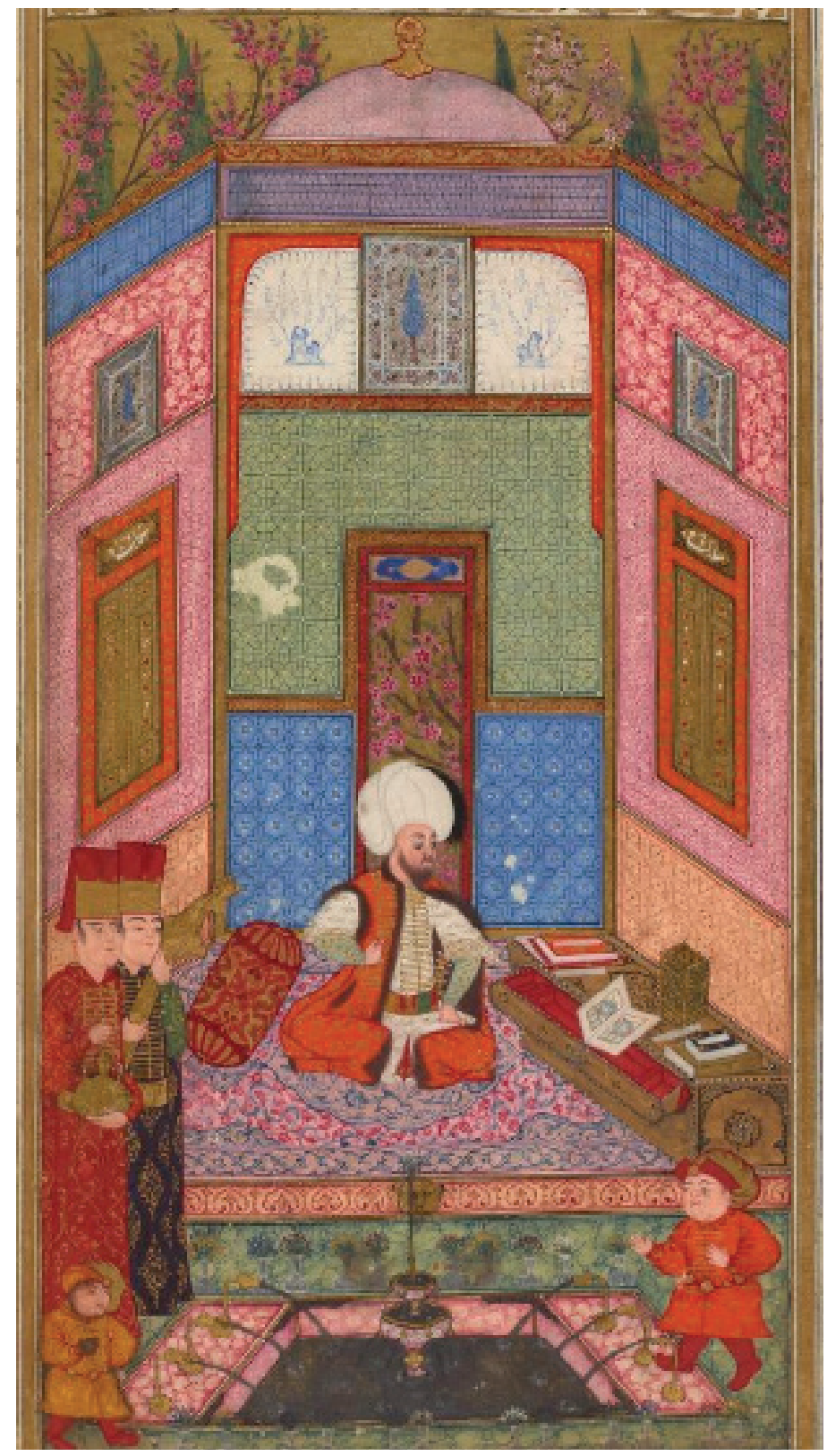

R. 4- III. Murad'ın sarayda bir köşkte kendisine sunulan, burç ve yıldızlarla ilgili tasvirli bir sayfası açı Matali'ü's-sa'ade'yi incelerken, Matali 'ü s-sa'ade ve Yenabi'u 's-siyade, 1582, PBNF, Turc 242, vr. $7 \mathrm{~b}$ (Serpil Bağc1, Filiz Çağman, Günsel Renda, Zeren Tanındı, Osmanlı Resim Sanatı, İstanbul, T. C. Kültür ve Turizm Bakanlığ1, 2006, s. 190, Resim 153). 


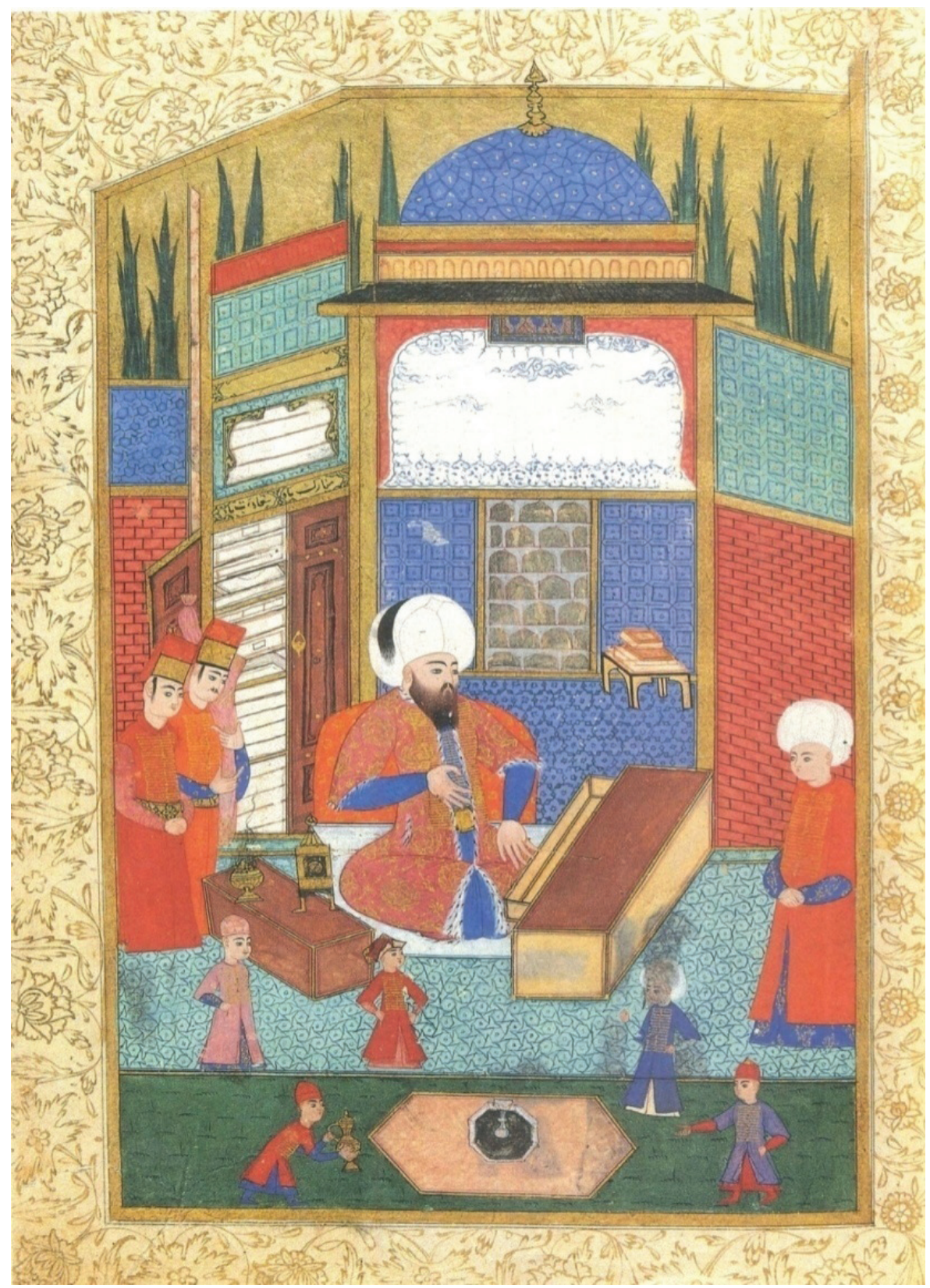

R. 5- Kanunî Sultan Süleyman'ın oğlu şehzade Mehmed'e nasihat etmesi, Şemâilnâme-i Âl-i Osman, 1590 civarı, TSMK, A. 3592, vr. 79a (Serpil Bağcı, Filiz Çağman, Günsel Renda, Zeren Tanındı, Osmanlı Resim Sanatı, İstanbul, T. C. Kültür ve Turizm Bakanlığı, 2006, s. 179, Resim 147). 
Türk kozmolojisinde kubbe ve kemer, göğü, manevi âlemi ve merkezi sembolize eden unsurlardir ${ }^{47}$. Bu unsurların mavi renkte olması da aynı anlamı pekiştiren bir mahiyet taşır. Zira Türklerde, mavi ve yeşil arasındaki tüm renkler gök renkleri olup gögü sembolize ederler ${ }^{48}$. Bu durum mevcut minyatürde yer alan mavi kubbenin göğü, ilahi olanı ve merkezi sembolize eden bir unsur olduğunu ve onun kompozisyon içerisine hükümdarın göksel yanına işaret etmek amacı ile yerleştirilmiş olabileceğini düşündürtür.

İlgili minyatürde mavi kubbenin hükümdarın göksel yanına yapmış olduğu düşünülen bu vurgu, kubbe altında resmedilen hükümdar kalıbı üzerinden de bir kez daha okunabilme imkânına sahiptir. Zira bir kubbe ya da bir kemerin hemen altında yer alan tahtında oturan hükümdar betimlemeleri kozmik bir mesaj ihtiva etmekte olup Türk resim sanatında olduğu gibi Budist resim sanatında, Roma dönemi hükümdar tasvirlerinde de sıklıkla kullanılmıştır ${ }^{49}$. İncelemiş olduğumuz minyatürde de bu kalıbın kullanılmış olduğu fark edilir. Bu kurgu, Türk hakanının Tanrı'nın mümessili olarak, gök ve yer arasında, gökte Tanrının, yerde ise yer ve suyun yardımı ile kullarının üzerinde oturmuş olduğuna dair inancın görsel bir dile dönüştürülmüş biçimi gibi görünmekte olup bu anlamı ile de sultanın göksel yanına işaret eden bir sembolik anlama sahiptir.

Sultanın hemen altında, mavi kubbe ile aynı dikey hat üzerinde yer alan havuz unsuru ise kompozisyon içerisinde bulunduğu yer de dikkate alındığında Türk kozmolojisindeki üçlü evren anlayışında yeraltı katmanı ile özdeşleştirilen yer altı sularına tekabül ediyor gibi görünmektedir. Yer altı katmanı ile özdeşleştirilmiş olan yer altı, kimi zaman bir göl veya deniz ile de yer değiştirmiştir ${ }^{50}$. Su, yerin derinliklerinden gelerek onun bütün gizemini taşıyan bir yer altı simgesi olarak ilahi gücün gökyüzünden yeryüzüne iletilmesine aracılık eden bir sem-

47 Titus Bruckhardt, Doğu'da ve Batı'da Kutsal Sanat, İstanbul, İnsan, 2017, s. 45, 104; Ahmet Çayc1, Íslam Mimarisinde Anlam ve Sembol, Konya, Palet Yayınları, 2017, s. 65, 200, 203, 207; İsmail Taş, a.g.e., s. 207, 208, 209; Simge Özer Pınarbaşı “"Taht Tiplerinin Oluşmasında İnançların Etkisi”, Sanat ve İnanç 1, Rıfkı Melûl Meriç Anısına, İstanbul, Mimar Sinan Güzel Sanatlar Üniversitesi Tük Sanat Tarihi Uygulama ve Araştırma Merkezi, 2004, s. 79.

48 Titus Bruckhardt, a.g.e., s. 82, 97; Bahattin Ögel, Türk Kültür Tarihine Giriş: Türklerde Tŭg ve Bayrak (Hunlardan Osmanlılara), c. 6, Ankara, Kültür Bakanlığı, 1989, s. 463; Reşat Genç, Türk Inanışları ile Milli Geleneklerinde Renkler ve Sarı Kırmızı Yeşil, Ankara, Atatürk Kültür Merkezi, 2009, s. 2, 28.

49 Ahmet Çaycı, Selçuklularda Egemenlik Sembolleri, İstanbul, İz Yayıncılık, 2008, s. 162,

50 Ahmet Çaycı, a.g.e., s. 162; Rövşen Alizade, Türk Halk Kültürü ve Tarihi, İstanbul, Karma Kitaplar, 2014, s. 373. 
bolik anlama da sahiptir ${ }^{51}$. Günkut Akın, dini mimaride ve saray mimarisinde yer alan havuz unsurunun kozmik bir anlama sahip olduğunu, bu havuzun yeri (yeraltın1) ve göğ (cenneti) birleştirdiğine inanılan gök direğinin (axis mundi) yeryüzünde son bulduğu noktayı sembolize ettiğini belirtir ${ }^{52}$. Günkut, bu havuzun sahip olduğu konumu ile göksel olanla, ilahi olan arasındaki iletişime olanak sağlayan bir işleve sahip olduğu bilgisini de ekler ${ }^{53}$. Nitekim Emevi ve Abbasi saraylarında yer alan havuzlar da böylesi bir simgesel anlama sahiptirler ${ }^{54}$.

Öyleyse mavi kubbenin göğe, dairevi havuzun yer altı sularına (yer altına) tekabül ettiği bu kurguda padişahın bu ikisi arasındaki dikey konumu "yerin ve göğün hükümdarı" imgesinin görsel bir şemasını teşekkül ediyor gibi görünmektedir (bkz. R. 3; Ç. 1, Ç. 2).

Mevcut minyatürün sahip olduğu dikey kurgunun altını çizmiş olduğu "yerin ve gögün hükümdarı" imgesi, Türk kozmolojisinde evrenin merkezinde yer ile göğü, ruh âlemi ile madde âlemini birleştiren bir kutlu kap1 ${ }^{55}$ olduğuna inanılan Kutup Yıldızı (gök direği) ve kozmik merkez kavramları üzerinden de bir kez daha okunabilme imkânına sahiptir. Türk kozmoloji inancına göre Türkün vatanı (yer-su), hükümdarlık merkezi, hükümdarın ikametgâh1, saray ve hükümdar kavramlarının her biri birer merkez sembolleri olup bunların her birinin tıpkı Kutup Yıldızı gibi dünyanın ve evrenin merkezinde ${ }^{56}$ yer aldığına inanılmıştır. Bu minvalde Türkler, kâinatın merkezinde yer aldığını düşündükleri hükümdarlık merkezinin "Altun" ya da "Temur Kazık" denilen "Kutup Yıldızı"nın (gök direği) tam altına rast gelen "yer-su" sahasında, yüksek bir dağ misali, set üzerinde bu-

51 N. Çiçek Akçıl Harmankaya, Mimar Sinan Camilerinde Sembolizm, İstanbul, Kitabevi, 2018, s. 146; Günkut Akin, "The Muezzin Mahfili and Pool of the Selimiye Mosque in Edirne", Muqarnas, volume 12, 1995, s. 77; Fatma Sinem Ery1lmaz Arenas Vives, a.g.t., s. 202.

52 Günkut Akin, "The Muezzin Mahfili and Pool of the Selimiye Mosque in Edirne", Muqarnas, volume 12, 1995, s. 77.

53 Çiçek Akçıl Harmankaya, Mimar Sinan Camilerinde Sembolizm, İstanbul, Kitabevi, 2018, s. 146; Günkut Akin, "The Muezzin Mahfili and Pool of the Selimiye Mosque in Edirne", Muqarnas, volume 12, 1995, s. 77.

54 Çiçek Akçıl Harmankaya, a.g.e., s. 146.

55 Bahattin Ögel, Türk Mitolojisi, c. 1, s. 128; Bahattin Ögel, Türk Mitolojisi, c. 2, s. 214; İsmail Taş, a.g.e., s. 148; Ünal Asan, Anıt Ăgaç Kavramının Fiziksel, Görsel ve Sosyokültürel Dayanaklarl, İstanbul, Arkeoloji ve Sanat Yayınları, 2016, s. 151, 155, 159; Fuzuli Bayat, a.g.e., s. 290; Pervin Ergun, Türk Kültüründe Ağaç Kültü, Ankara, Atatürk Kültür Merkezi Başkanlığ1, 2017, s. 197.

56 Bahattin Ögel, Türk Mitolojisi, c. 2, s. 319, 327; Bernard Lewis, İslâm'in Siyasal Söylemi, Ankara, Phoenix, 2007, s. 18; İsmail Taş, a.g.e., s. 159, 231; Fuzuli Bayat, a.g.e., s. 46. 
lunduğu inancını benimsemiş̧lerdir ${ }^{57}$. Bizatihi kendisi de bir merkez olan hükümdar Türkün yer ve suyunun sahibi olarak bulunduğu bu konumda tanrıdan aldığ kut, iktidar ve yönetme hakkı ile Gök-Tanrı tarafından bütün insanlığın üzerine hükümdar olarak oturtulmuş, onun mümessili say1lmıştır ${ }^{58}$. Bu durum Türklerdeki evren katları arasında görülen hükümdar merkezli iletişimin varlığını gözler önüne serer. Bu evren telakkisinde, hükümdar bulunduğu merkezi konumda yeri ve gögü, dünya ile ukbâyı birleştiren bir merkez, bir Kutup Yıldızı (Temur Kazık, gök direği) olarak görülmüştür ${ }^{59}$.

Tanrı'nın mümessili olan hükümdarın yeri ve göğü birleştiren bir merkez oluşu, Hunlardan itibaren eski Türklerde evrenin merkezinin (vatanın) aynı anda profan âlem ile ilahi âlemi birbirine bağlayan ve birbirinden ayıran bir nokta olduğu, hayatla ölümün burada birleştiği inancı ile de anlamca bir birliktelik oluşturur. Evren katları arasındaki hükümdar merkezli bu iletişime Oğuz Kağan Destanı'nda da rast gelinir. Destanda kozmik bir merkez olarak yeryüzünün merkezinde yer alan Oğuz, yapmış olduğu göksel ve yersel evlilikleri ile hem yerin hem de göğün merkezinde yer alarak yeri ve göğü birbirine eklemler ${ }^{60}$.

"Gögün direği” ve "Kutup Yıldızı" anlayışı Türkler Müslüman olduktan sonra da kendine yer bulmuş, Hz. Muhammed dinin direği, yerden göğe uzanan bir direk olarak görülmüştür ${ }^{11}$. Sonraki dönemde Aleviler bu görüşe Hz. Ali’yi de eklemişlerdir ${ }^{62}$.

Evrenin merkezindeki yurdunda ikamet eden hükümdarın, yeri ve göğü, maddeler âlemi ile ruhlar âlemini, dünya ile ukbâyı eklemleyen bu dikey hareketi, Osmanlılarda padişahların aynı zamanda bir halife olması üzerinden de kendine varlık alanı bulur. Bilindiği üzere Yavuz Sultan Selim'in 1517 yılında ${ }^{63}$ Misır'1 fethi ile birlikte halifelik Osmanlılara geçmiştir. Halifeliğin Osmanlılara geçmesi ile birlikte hem bir sultan hem de bir halife olan Osmanlı padişahı, aynı anda siyasi ve ruhani iktidarı kendi şahsında toplayan ${ }^{64}$ bu vesile ile dünya ile ukbâyı,

57 Bahattin Ögel, a.g.e., s. 319; Fuzuli Bayat, a.g.e., s. 46; İsmail Taş, a.g.e., s. 159; Mehmed Niyazi, a.g.e., s. 87-88.

58 Bahattin Ögel, a.g.e., s. 206, 459; Mehmed Niyazi, a.g.e., s. 48, 170; Cengiz Balc1, a.g.e., s. 47, 124, 129; Halil İnalcık, Osmanlı'da Devlet, Hukuk ve Adâlet, İstanbul, Kronik, 2017, s. 36; İsmail Taş, a.g.e., s. 159, 231.

59 İsmail Taş, a.g.e., s. 159, 231; Mehmed Niyazi, a.g.e., s. 87-88.

60 İsmail Taş, a.g.e., s. 163, 165, 202.

61 Bahattin Ögel, a.g.e., s. 213.

62 a.e., s. 214.

63 Bernard Lewis, a.g.e., s. 71.

64 Namık Sinan Turan, a.g.e., s. 227, 228. 
yer ile göğü birbirine eklemleyen bir merkez figüre dönüşmüştür. Bu doğrultuda bir söylem ile Halil İnalcık, iktidarın göksel ve dünyevi kökenlerine işaret eden "halife-sultan" unvanının ikili iktidarın ifadesi olduğunu belirtmiştir ${ }^{65}$. Nitekim Kanunî Sultan Süleyman da bir halife-sultan olması hasebi ile ikili iktidarı birleştiren bir merkez hükmündedir. Bu durum mevcut minyatürde padişahın ikili iktidarına atıf yapan bir görsel dilin varlığını akla getirir.

Mevcut minyatürdeki ikili iktidarın varlığ yasi otoriteyi tek bir hükümdarlık altında birleştirme isteği ile de örtüşür ${ }^{66}$. Nitekim onun sahip olduğu bu ikili iktidar kendi döneminde de altı çizilen bir durum olagelmiştir ${ }^{67}$. Bu minvalde kimi zaman Sünni İslam'ın halifesi, kimi zaman bünyesinde dini ve siyasi iktidarı barındıran cihanşümul bir "sahib-kıran" (mesiyanik bir kumandan), kimi zaman ise bir "müceddid" olarak nitelendirilmiştir ${ }^{68}$. İncelemiş olduğumuz minyatürün içerisinde yer aldığı Süleymannâme (TSMK, H. 1517)'nin metninde de Fethullah Çelebi, Sultan Süleyman'ın ruhani ve siyasi liderliğine işaret etmiş, sultanı "sahib-kıran" ve "müceddid" sıfatları ile birlikte nitelemiştir ${ }^{69}$.

Tüm bu bilgiler kompozisyonda, daha öncede belirtmiş olduğumuz üzere evrenin merkezinde, gök, yer ve yer altı katmanlarının merkezlerinden geçerek bunları birbirine bağladığına inanılan gök direği (Kutup Yıldızı) kavramı üzerinden yol alan bir dikey kurgunun varlığını düşündürtür (bkz. Ç. 2). Türk hükümdarının, evrenin merkezinde yer alan sarayında, yeri ve göğü birleştiren bir gök direği (Kutup Yıldızı), bir merkez oluşuna gönderme yaptığı düşünülen bu kurgu, "yerin ve göğün hükümdarı" imgesinin de altını çizer. Türk sultanı, üçlü evren kozmolojisinde gök ve yer altının tam ortasında, "yer"de, tahtında, evrenin merkezinde oturur.

Nakkaş A'nın, sultan, gök direği ve merkez kavramları üzerinden yol alan bu kozmik dikey kurguyu Süleymannâme (TSMK, H. 1517) içerisinde resmetmiş olduğu diğer sahnelerde de devam ettirmiş olduğu görülür (bkz. vr. 17b-18a, vr. 71a, vr. 98a, vr. 177a, vr. 189b, vr. 260a, vr. 309a, vr. 332a, vr. 346a, vr. 367a, vr. $441 \mathrm{a}$, vr. $519 \mathrm{a}$, vr. $557 \mathrm{a}$, vr. $570 \mathrm{a}$, vr. $583 \mathrm{a}$, vr. 592a, vr. $600 \mathrm{a}$, vr. $603 \mathrm{a}$ ) (bkz. R. 6; Ç. 3).

65 a.e., s. 228.

66 Kaya Şahin, Kanunî Devrinde Imparatorluk ve İktidar Celalzâde Mustafa ve 16. Yüzyıl Osmanlı Dünyası, İstanbul, Yap1 Kredi Yayınları, 2014, s. 77.

67 Fatma Sinem Ery1lmaz Arenas Vives, a.g.t., , s. 171.

68 Kaya Şahin, a.g.e., s. 72, 82; Fatma Sinem Ery1lmaz Arenas Vives, a.g.t. , s. 171.

69 Fatma Sinem Eryılmaz Arenas Vives, a.g.t., s. 171, 173, 175, 178, 207. 
Süleymannâme (TSMK, H. 1517) Vr. 503a'da Yer Alan Elçi Kabul Sahnesinde

Kozmik Merkez Üzerinden Yol Alan İktidar Dili / Zaliha Peçe

95

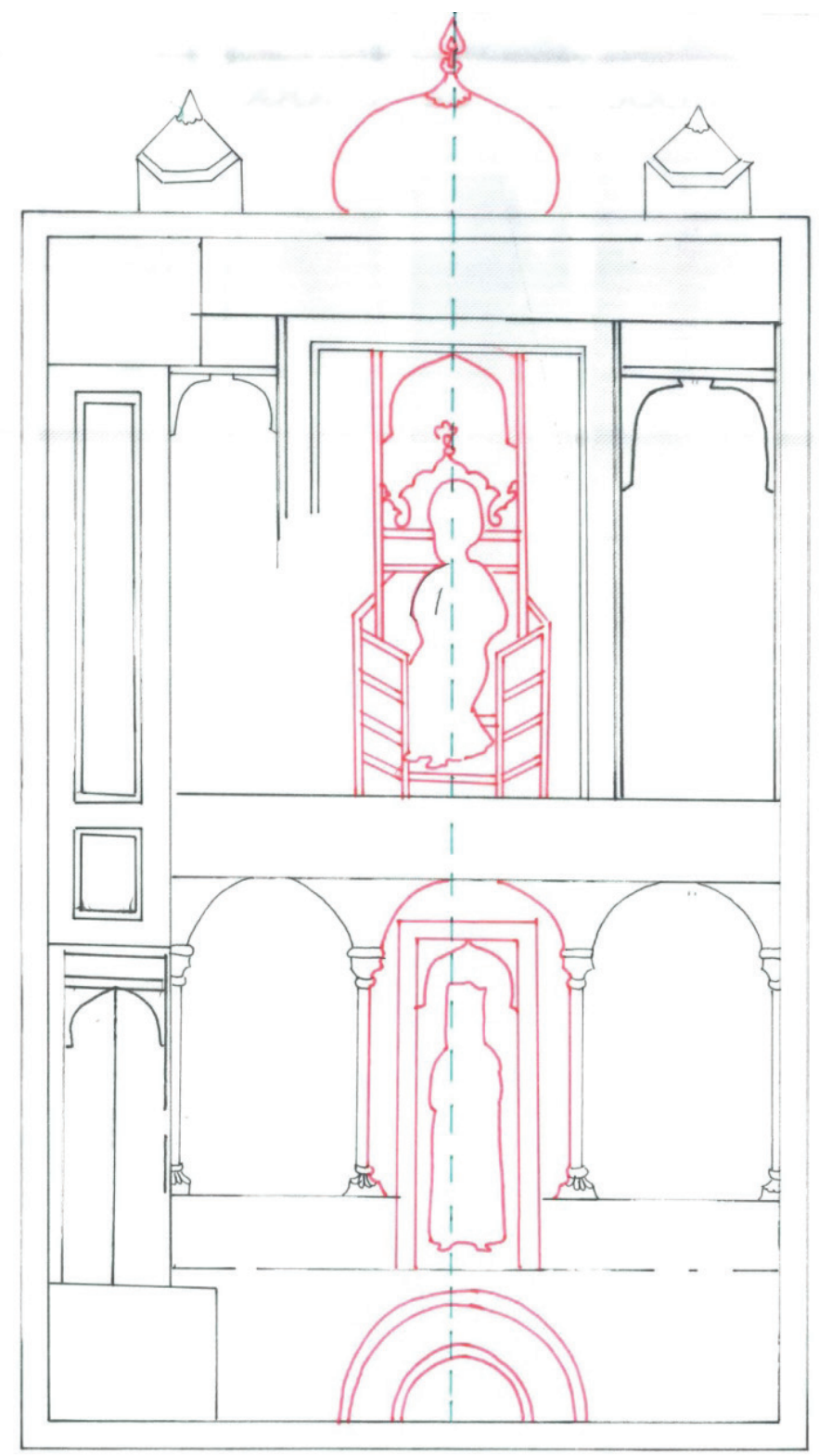

Ç. 2 


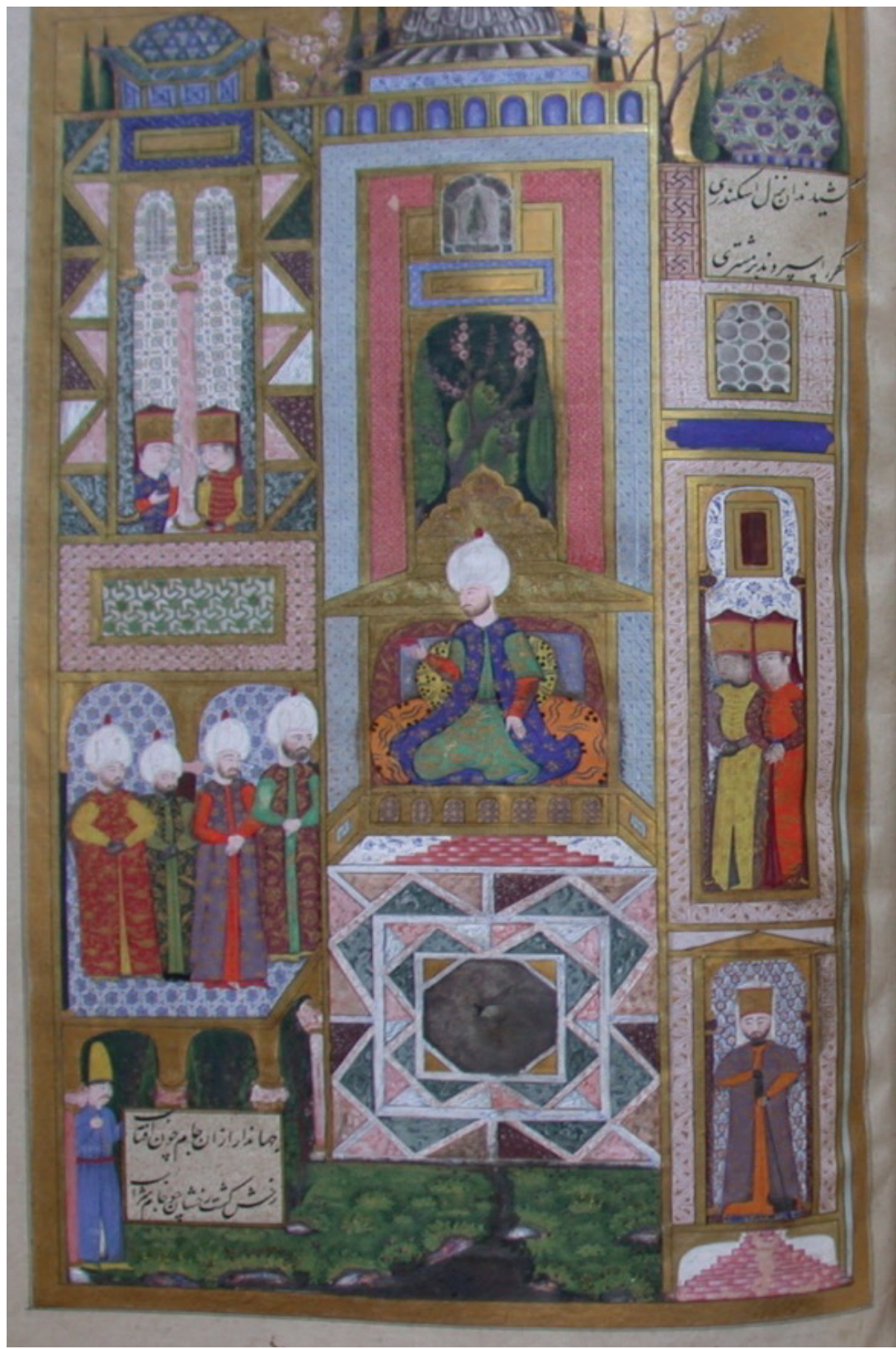

R. 6- İskender Paşa'nın cam-1 Cemşid'i Kanunî Sultan Süleyman'a sunuşu, Süleymannâme, 1558, TSMK, H. 1517, vr. 557a (Esin At1l, Süleymannâme The Illustrated History of Süleyman the Magnificent, New York, Harry and Abrams Inc., 1986, s. 200). 


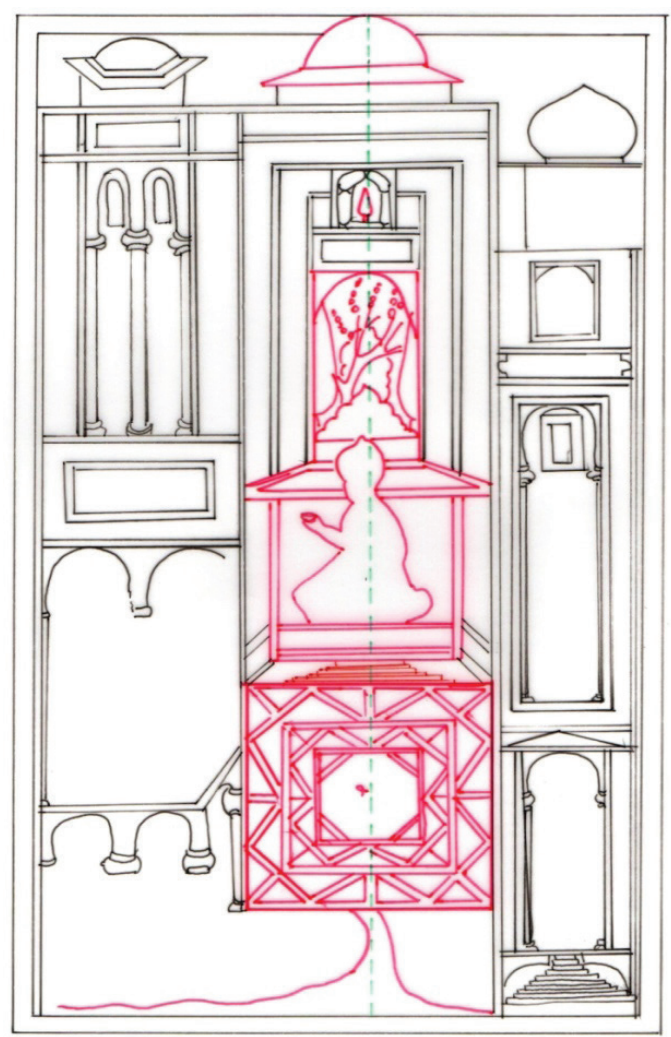

Ç. 3

İncelemiş olduğumuz minyatürde kompozisyonun merkezinden geçen dikey aksın, yukarıdan aşağıya sırası ile her biri birer merkez ve iktidar sembolü olan mavi kubbe, kemerli niş, sarı kaftanlı padişah, altıgen formlu altın taht, arz odasına giriş kapısı, kapı ağası ve son olarak yeşillendirilmiş bir avlunun tam ortasında yer alan dairevi formdaki bir havuzdan müteşekkil olması da bu aksın yapmış olduğu merkez vurgusunu pekiştirir bir mahiyet taşıyor gibi görünmektedir (bkz. Ç. 2). Bu aks, kompozisyon içerisindeki merkezi konumu, sahip olduğu dikeyliği ve üzerinde yer alan merkez ve iktidar vurgusu yapan unsurlar ile birlikte adeta evrenin merkezinde, yeri ve gögü, ruh âlemi ile maddi âlemi birleştirdiğine inan1lan Kutup Yıldızı'nı (Temur Kazık, gök direği) çağrıştıran bir mahiyet taşır. Türk hükümdarının bir merkez olduğu ve Osmanlı padişahlarının dünyevi iktidarın sahibi bir sultan ve aynı zamanda bir halife oldukları göz önünde bulundurulduğunda, bu dikey aks ve bu aks üzerinde yer alan unsurların birlikteliği mevcut kompozisyonda Türk-İ́slâm düşüncesinin sentez edildiği bir hükümdar algısının varlığını düşündürtür. Kompozisyon bu şekli ile bir kez daha ikili iktidarı bünye- 
sinde barındıran "yeri ve göğü birleştiren hükümdar" imgesinin altını çiziyor gibi görünmektedir. $\mathrm{Bu}$ aksın bahsedilen imgenin altını ne şekilde çiziyor olduğunu anlayabilmek için aksın üzerinde alt alta yer alan her bir unsurun sembolik anlamlarına kısaca değinmek gerekir.

Dikey aksın en tepesinde yer alan mavi kubbe daha önce de belirtmiş olduğumuz gibi göğü, manevi âlemi, semâvatı, ilahi olanı ve dahi merkezi sembolize eder. Mavi kubbenin hemen altında yer alan kemerli niş de yine kubbe gibi göğü, manevi âlemi, semâvatı ve merkezi sembolize eder.

Kemerli nişin hemen altında, altın tahtında, sarı kaftanı ile oturan padişah figürü de sahip olduğu tüm unsurlar ile birlikte merkez kavramına atıf yapar. Zira daha önce de belirtilmiş olduğu gibi Türklerde padişah bir merkez, yeri göğü eklemleyen "Kutup Yıldızı" hükmündedir. Padişahın üzerine giymiş olduğu kaftanın sahip olduğu sarı renk de merkez kavramının altını çizen bir unsur olarak kompozisyon içerisinde bulunuyor olmalıdır. Zira sarı ve altın Türklerde hükümdarlara özgü bir renk olup merkezi ve vatanı sembolize ederler ${ }^{70}$.

Padişahın üzerine oturmuş olduğu altın taht bir egemenlik ve hükümdarlık alâmeti olmasının yanında aynı zamanda bir merkez sembolüdür ${ }^{71}$. Taht ayrıca dinsel bir simgedir ve onun bu simgeselliği tahtta oturan kişinin dinsel kimliği ile ilintili olmuştur ${ }^{72}$. Özellikle din ve devlet ilişkisinin iç içe geçmiş olduğu erken dönemlerde tahtın dinsel niteliği göz ardı edilemez bir mahiyettedir ${ }^{73}$. Bu toplumlarda devleti yöneten taht sahibi kişilerin sıklıkla dinsel bir kimlik taşıması, kralların ve tahtın gökten indirildiğine ya da göğe çıkılarak tahta oturulduğuna

70 Fuzuli Bayat, a.g.e., s. 39, 46; Bayram Durbilmez, Türk Dünyası Kültürü, İstanbul, Ötüken, 2017, s. 74; Annemarie Von Gabain, "Renklerin Sembolik Anlamları", Türkoloji Dergisi, c. 3, 1968, s. 107; Reşat Genç, a.g.e., s. 35; Fatmagül Küçük Tursun, "Türk Atasözlerinde Renkler”, Renk Kitabı, İstanbul, Kitabevi, 2017, s. 22; Simge Özer Pınarbaşı, Çağlar Boyu Tahtın Simgesel Anlamları Işığında Türk Tahtları, Ankara, T. C. Kültür ve Turizm Bakanlığı Yayınlar1, 2004, s. 55.

71 İbrahim Kafesoğlu, Türk Milli Kültürü, İstanbul, Ötüken, 2017, s. 257, 258; Ali Arslan, Türk Tarihinde Lider ve Liderlik Anlayışı, İstanbul, Kitabevi, 2014, s. 29; Ahmet Çaycı, a.g.e., s. 77; Bahattin Ögel, Türklerde Devlet Anlayışı, s. 158; Simge Özer Pınarbaşı, a.g.e., s. 18; Bernard Lewis, a.g.e., s. 185; Erdoğan Merçil, Selçuklular'da Hükümdarlık Alâmetleri, Ankara, Türk Tarih Kurumu, 2007, s. 132; Salim Koca, “Türkiye Selçuklu Devleti Hükümdarlarının Aldıkları ve Kullanılan Hâkimiyet ve Hükümdarlık Sembolleri”, III. Milli Selçuklu Kültürü ve Medeniyeti Semineri Bildirileri 20-22 Mayıs, Konya, Selçuk Üniversitesi Yayınları, 1994, s. 155.

72 Simge Özer Pınarbaşı, a.g.e., s. 18, 20.

73 a.e., s. 20. 
dair inanışlar ${ }^{74}$ tahtın üzerinde oturan kişinin kimliği ile iniltili olarak dinsel bir simge oluşunu gözler önüne serer.

Tek tanrılı dinlerin kabulüyle birlikte Tanrı krallar ortadan kalkarken, hükümdarlar dinsel bir kimlik taşımaya devam etmiş buna paralel olarak taht unsuru da hükümdarın dinsel kimliği ile bağlantılı bir unsur olmayı sürdürmüştür ${ }^{75}$.

Türk kağanının gökyüzü ile olan ilişkisi dolayısıyla, kutsal ve dinsel bir kimliğe sahip oluşu, onun Tanrı tarafından aldığı kut ile tahtta oturuyor olmasi ${ }^{76}$ hükümdar ve taht arasındaki dinsel bağlamın Türklerde de benimsenmiş olduğunu gözler önüne serer. İslamiyet'in kabulü öncesi Türklerde hükümdarlık kavramının içermiş olduğu bu dinsel kimlik Türklerin İslamiyet'e girişiyle birlikte ortaya çıkan "halife-sultan" kavramı üzerinden de varlığını devam ettirmiştir"

Öyleyse mevcut minyatürde yer alan altın taht, yeri ve göğü, dünyevi ve manevi iktidarı birleştiren dinsel nitelikli bir merkez motif olarak işlev görüyor gibi gözükmektedir. Bir kozmik sembol olan tahtın ${ }^{78}$ sahip olduğu bu ikili anlam, yersel ve göksel unsurları birleştiren bir unsur olarak kompozisyonun orta ekseni üzerinde yer alan dikey aksın varlığı ile de bir anlam birlikteliği oluşturur.

Tahtlarda yaygın olarak kullanılan kimi süslemeler de gökyüzü ile ilişkili olup tahtın kozmolojik anlamını güçlendirir mahiyettedirler ${ }^{79}$. Bu doğrultuda incelenilen minyatürde, tahtın altıgen formda olması gök ve merkez sembolizmi ile bağlantılı olarak tahtın kozmik anlamını güçlendirir bir nitelik taşıyor gibi görünmektedir. Nitekim Ahmet Çaycı'ının altıgen formun göksel bir sembol olduğunu, Günkut Akın'ın ise bu formun merkezi sembolize ettiğini, sekiz ve altı sayılarının göğü, yeri ve yer altını birleştiren eksenin tam ortasında yer alan bir merkezi sembolize ettiğini belirtmiş ${ }^{80}$ olmaları yukarıda yapılmış olan tespiti teyit eder bir nitelik taşır.

İktidarın gücünü ve merkez kavramının altını çizen bu taht, altından yapılmış olması ile de aynı vurguyu devam ettirir gibi görünmektedir. Zira altın, Türklerde

74 a.e., s. 20,44

75 a.e., s. 25.

76 a.e., s. 22, 23; Mehmed Niyazi, a.g.e., s. 36, 70.

77 Simge Özer Pınarbaşı, a.g.e., s. 24.

78 a.e., s. 44.

79 a.e., s. 18, 44.

80 Ahmet Çaycı, İslam Mimarisinde Anlam ve Sembol, s. 71; Günkut Akin, a.g.m., s. 76; Günkut Akın, "Edirne Selimiye Camii'ndeki Müezzin Mahfili Üzerine Düşünceler", Uluslar arası Mimar Sinan Sempozyumu Bildirileri (Ankara, 24-27 Ekim 1988), Ankara, Türk Tarih Kurumu Basımevi, 1996, s. 36. 
bir hükümdarlık ve merkez sembolüdür ${ }^{81}$. Bu durum altıgen formlu altın tahtın, sahip olduğu tüm bu özellikleri ile hükümdar, gök ve merkez kavramlarına bir gönderme yapıyor olabileceği fikrini akla getirir. $\mathrm{Bu}$ ise minyatürün orta ekseni üzerinde yer alan dikey aksın yapmış olduğu kozmik merkez vurgusunu pekiştirir bir mahiyet taşır.

Dikey hat boyunca yer alan bir diğer unsur ise arzın gerçekleştiği mekâna açılan giriş kapısıdır. Mevcut minyatürde resmedilen elçi kabulü sahnesi gerçekte Halep'te ki bir sarayda vuku bulmuş olmakla birlikte eserin Topkapı Sarayı Arz Odası'nda gerçekleşen elçi kabullerinin yer aldığı 332a, 471b ve 519a'da yer alan minyatürlerine bakıldığında, bu 503a'da resmedilen mekânın 332a, 471b ve 519a'da ki Topkapı Sarayı Arz Odası ile benzer bir kurguya sahip olduğu fark edilir $^{82}$ (bkz. R. 7, R.8).

81 Ahmet Çayc1, Selçuklularda Egemenlik Sembolleri, s. 77; Annemarie Von Gabain, a.g.m., s. 109.

82 Esin Attl, a.g.e., s. 201 


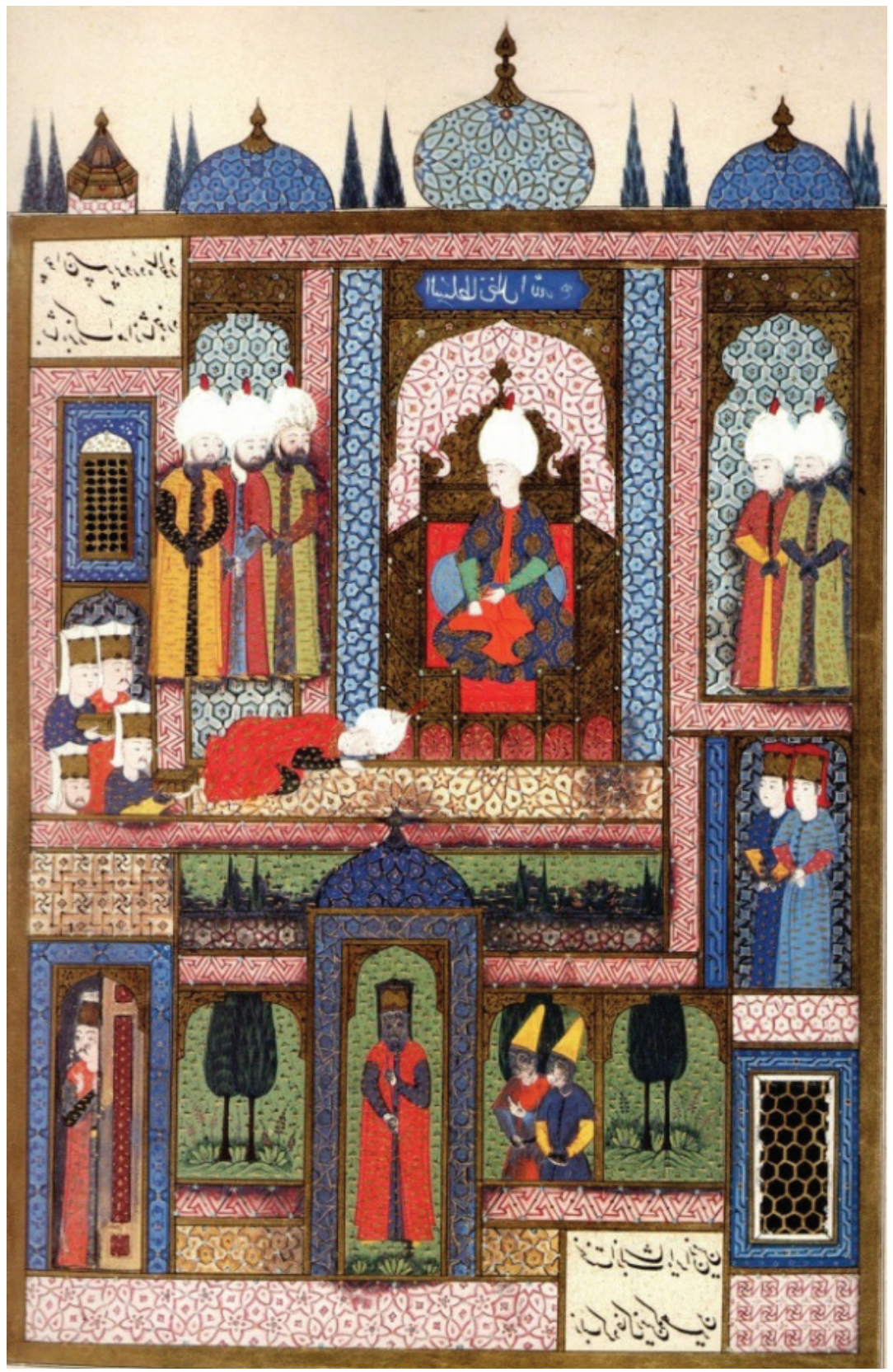

R. 7- İranlı elçinin huzura kabulü, Süleymannâme, 1558, TSMK, H. 1517, vr. 332a (Esin At1l, Süleymannâme The Illustrated History of Süleyman the Magnificent, New York, Harry and Abrams Inc., 1986, s. 160). 


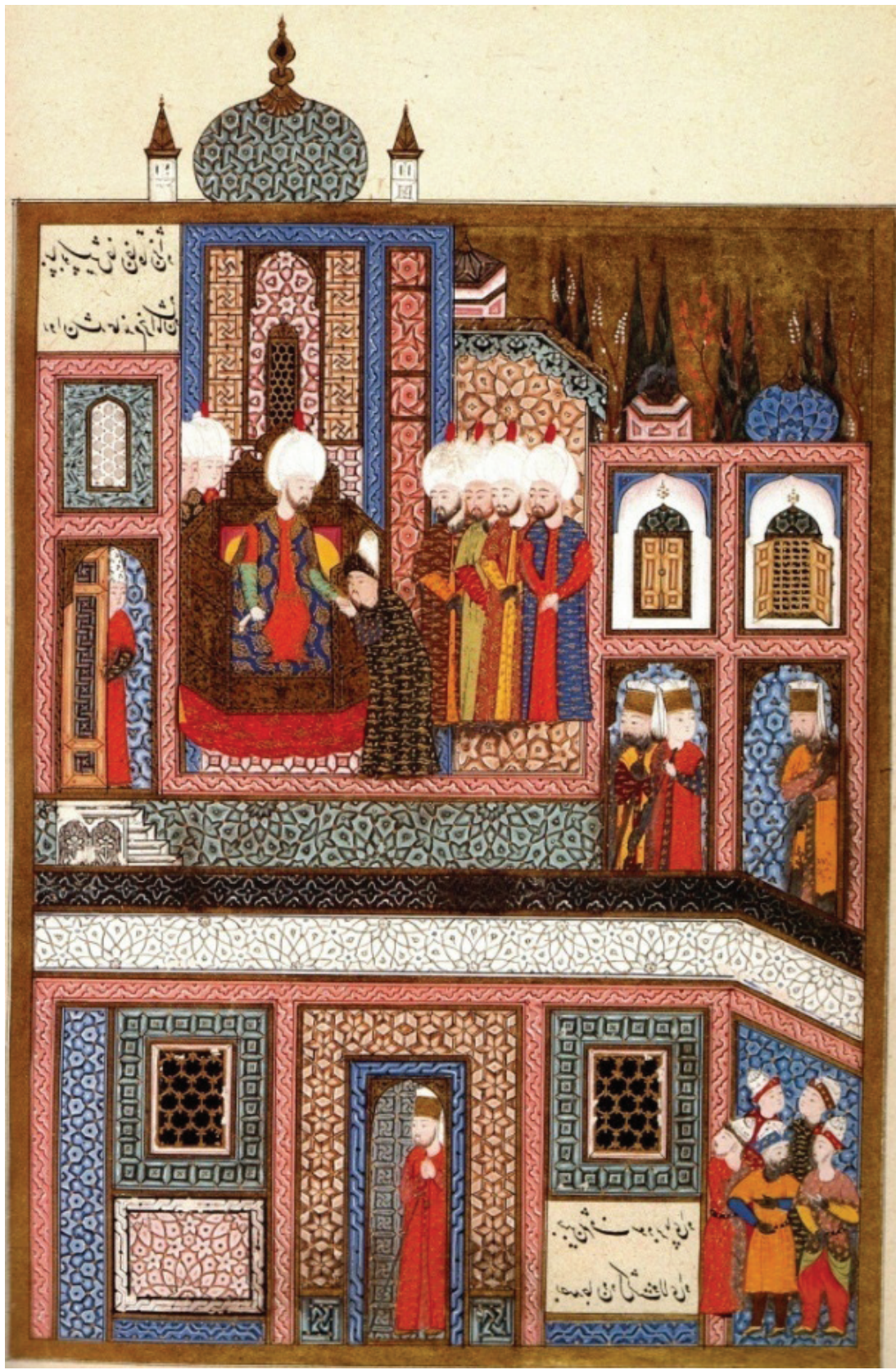

R. 8- Devler Giray Han'ın padişahı ziyareti, Süleymannâme, 1558, TSMK, H. 1517, vr. 519a (Esin At11, Süleymannâme The Illustrated History of Süleyman the Magnificent, New York, Harry and Abrams Inc., 1986, s. 206). 
$\mathrm{Bu}$ durumda mevcut kompozisyonda yer alan kapı, mekânın genel kurgusu dikkate alındığında Topkapı Sarayı'ndaki Bâbüs's-saâde kapısına denk düşer ki, Arz Odası'na geçişi sağlayan bu kapı padişahın varlığını, onun yüce gücünü temsil eder ${ }^{83}$. Kapı unsuru bütün yüce makamları simgesel olarak ortaya koyan bir kavram olup hükümdar ve sarayı ile bağlantılı bir unsur ${ }^{84}$ olarak hükümdarın gücüne vurgu yapar ${ }^{85}$.

Kapının tam orta kısmında, hükümdarın sürekli hizmetinde olan, misafirleri ağırlayan ${ }^{86}$ ve mevcut minyatür de ise saraya ait kapıyı koruma görevini ifa eden, yüzü seyirciye dönük eli asalı kapı ağası da iktidar vurgusu açısından önemlidir. Bu figür bir hâkimiyet sembolü olan kapıyı koruma görevini üstlenmiş olması ve bir egemenlik ve hükümdarlık sembolü olan asası ${ }^{87}$ ile kompozisyonda iktidarı taltif edici bir unsur olarak yer alıyor gibi görünmektedir.

Kapı ağasının yüzünün ve bakışlarının seyirciye dönük olarak resmedilmesi de oldukça manidardır. Zira kapı ağasının seyirciyle göz göze gelmekte tereddüt etmeyen, kendinden emin, donuk bir bakışla resmedilmiş olması izleyici üzerinde bir hâkimiyet kuruyor gibi görünmektedir. Seyirci ile göz göze gelen, onun üzerinde hâkimiyet kuran bu bakış adeta iktidarın ta kendisidir.

Aynı dikey hat üzerinde yer alan son unsur olan dairevi formlu havuz da bir başka iktidar ve merkez sembolüdür. Daha önce belirtmiş olduğumuz gibi bu minyatürde yer alan havuz unsurunun, Türk kozmolojisindeki gök, yer ve yer altından oluşan üçlü evren anlayışındaki yer altına (yer altı sularına) tekabül ediyor olabileceği düşünülmektedir.

Suyun yer altı unsuru oluşu onun merkez sembolü oluşunun da kapısını aralar. Zira birbirine paralel üç yatay düzlem olarak tasarlanan evren tabakalarının (gök-yer-yeraltı) tam ortalarından geçtiği düşünülen bir dikey eksen vasıtası ile birbirlerine bağlandıkları düşünülür. Türk kozmolojisine göre dünyanın ve evrenin merkezi olduğu düşünülen bu dikey eksen, en alt tabakada yer alan su yüzeyinin içine girerek, yerin derinliklerine ulaşır ${ }^{88}$. Bu bağlamda su, havuz ve göl

83 Mustafa Sabri Küęükaşçı, a.g.m., s. 173; Gülru Necipoğlu, 15. ve 16. Yüzyılda Topkapı Sarayı Mimarî, Tören ve İktidar, İstanbul, Yap1 Kredi Yayınları, 2014, s. 59, 60

84 Gülru Necipoğlu, a.g.e., s. 177-195.

85 H. Canan Cimilli, “Topkapı Sarayı'nın Anıtsal Tören Kapılarındaki Simgesellik, Kapı Kavramı ve Törenler ile Bağlantısı”, Filiz Çağman'a Armağan, İstanbul, Lale Yayıncılık, 2018, s. 178.

86 Ahmet Çayc1, a.g.e., s. 225.

87 a.e., s. 221.

88 N. Çiçek Akçıl Harmankaya, a.g.e., s. 146, dipnot: 486. 
unsurları da dünyanın merkezi işlevini vurgular bir mahiyet taşırlar ${ }^{89}$. Su kenarlarının kâinatın merkezinde yer aldıkları düşünülen Türk yurtlarının ikamet ettikleri yerler ${ }^{90}$ olması da su unsurunun bir merkez sembolü oluşunu gözler önüne serer.

Günkut Akın, Sasanilerin tapınak ve saraylarını doğal veya yapay bir gölün merkezinden geçen bir eksen üzerine yerleştirmelerinin Türklerdeki gök, yer ve yer altı (göl-deniz) kozmolojisine benzer bir inançla ortaklık gösterdiğini belirtir ${ }^{91}$. Ona göre buradan yola çıkarak havuzun bir dünya egemenliği ve hükümdar gücü sembolü olduğu daha kolay anlaş1lır ${ }^{92}$. Günkut, dünyanın merkezinden geçen axis mundi inancı dışında, yer altı güçlerine olan inancın da burada rol oynuyor olabileceğini, havuzun başında duran hükümdarın, yer altı dünyasına açılan kapının ağzında durduğuna ve burada yerin altındaki güçlerle iletişimi elinde tutmakta olduğunu belirtir ${ }^{93}$.

Asya'da birçok kültür çevresinde simgesel nitelikli havuzlar sarayın ayrılmaz bir parçası olarak var olmuştur ${ }^{94}$. Bu egemenlik simgesinin saray ve cami mimarisindeki ortak kullanımı erken İslâmiyet dönemine kadar geriye gitmektedir ${ }^{95}$. Topkapı Sarayı'nda sultanın bulunduğu ve kabuller yaptığı mekânlarda da havuz unsuru yaygın bir şekilde kullanılmıştır ${ }^{96}$. Semra Ögel bu havuzların evrenin merkezi hükmünde bir sembolizmi barındırdığını belirtir ${ }^{97}$.

Havuzun, saray ile birliktelik kazanan sembolik anlamının minyatürlerde açı bir şekilde müşahede edildiğini belirten Günkut Akın, tahtında oturan padişah ve önünde yer alan havuzdan meydana gelen geleneksel şemanın bahsetmiş olduğumuz merkez ve egemenlik sembolizminin anlamını ve kökenini açıklayacak mahiyet taşıdığını belirtir ${ }^{98}$. Bu anlama paralel olarak Mustafa Sabri Küçükaşçı da su ve nehir gibi unsurların Osmanlı padişahlarının karaların ve denizlerin sul-

89 a.y.; İsmail Taşpınar, "Halk İnançlarında Su”, Z Kültür Sanat Şehir, sa. 2, İstanbul, Zeytinburnu Belediyesi, 2017, s. 35.

90 Bahattin Ögel, Türk Mitolojisi, c. 1, s. 90, 91, 92.

91 Günkut Akın, a.g.m., s. 30, dipnot 29.

92 a.y.

93 a.y.

94 Aynı makale, s. 28.

95 Aynı makale, s. 28; Muhittin Aykut, “Türk Mimarlığında Su Kompozisyonları Kullanımı”, 8. Uluslar arası Türk Sanatları Kongresi Bildiriler, (23-27 Eylül 1991 İstanbul), c. 1, Ankara, T. C. Kültür Bakanlığı Yayınları, 1995, s. 205.

96 Mustafa Sabri Küçükaşçı, a.g.m., s. 173.

97 Semra Ögel, Anadolu’nun Selçuklu Çehresi, İstanbul, Akbank, 1994, s. 69.

98 Günkut Akın, a.g.m., s. 30. 
tanı olduğunu vurgulayan bir unsur olduğunu belirtir99. Dikkat edilecek olursa incelemiş olduğumuz minyatürde de tahtında oturan padişah ve önünde yer alan havuzdan oluşan geleneksel şemanın kullanılmış olduğu görülür. Aslına bakılırsa bu havuzun sahip olduğu daire formunun kendisi de tek başına üzerinde tüm yönlerin birleştiği bir merkez sembolüdür ${ }^{100}$.

Suyun, içen kişiye ebedi yaşam bahşettiğine inanılan ab-1 hayat ${ }^{101}$ ile olan bağlantısı da göz önünde bulundurulduğunda mevcut minyatürde yer alan havuzun, yalnızca sultanın gök ve yeraltı arasında, bir merkez ve egemenlik sembolü oluşuna vurgu yapan bir kompozisyon unsuru olmakla kalmayıp aynı zamanda yerin ve yer altı dünyasının, karaların ve denizin, yerin ve göğün sahibi olan sultanın, gücüne, imparatorluğun devamlılığına vurgu yapan bir kompozisyon unsuru olarak ta minyatür içerisine yerleştirilmiş olabileceğini düşündürtür.

Görüldüğü üzere bu dikey aksın üzerinde yer alan her bir unsur, gerek merkez gerekse bir iktidar sembolü oluşu ile dikey aksın yapmış olduğu merkez, yeri ve gögü birleştiren direk vurgusunu anlamca destekler. Bu kurgu bir kez daha "yeri ve göğü, dünya ile ukbâyı birleştiren hükümdar" imgesinin altını çizerek mevcut kompozisyonda kozmik merkez inancı üzerinden ilerleyen bir iktidar dilinin varlığını gözler önüne serer.

\section{Sonuç}

Süleymannâme, vr. 503a'da yer alan elçi kabul sahnesinde Türk kozmoloji inanc1 üzerinden yol alan bir iktidar dilinin var olduğu düşünülmektedir. $\mathrm{Bu}$ dil öncelikli olarak gök, yer ve yer altı katmanlarından müteşekkil üçlü evren anlayışından istifade edilerek inşa edilmiş olan dikey kompozisyon kurgusu ile varlığını belli eder. Nakkaş tarafından bilinçli olarak yapıldığ 1 kesin olarak bilinmeyen bu dikey kozmik kurguda, sultanın göğü temsil eden mavi kubbe ile yer altını sembolize eden dairevi formlu havuzun arasında konumlanmış olduğu fark edilir. Sultanın kompozisyon içerisindeki bu konumu, göğün ve yer altı sularının desteğini alarak tahtında oturan Türk hükümdarı imgesinin görsel bir dile aktarılış biçimi gibi görünmektedir.

99 Mustafa Sabri Küçükaşçı, a.g.m., s. 173.

100 Semra Ögel, a.g.e., s. 67.

101 Rövşen Alizade, a.g.e., s. 193; İsmail Taşpınar, a.g.m., s. 36; Mircea Eliade, "Su ve Su Simgeleri”, Z Kültür Sanat Şehir, sa. 2, İstanbul, Zeytinburnu Belediyesi, 2017, s. 41; İsmail Taşpınar, "Su, Dinler ve Ritüeller", Z Kültür Sanat Şehir, sa. 2, İstanbul, Zeytinburnu Belediyesi, 2017, s. 62; Murat Öztabak, "Âb-1 hayat”, Z Kültür Sanat Şehir, sa. 2, İstanbul, Zeytinburnu Belediyesi, 2017, s. 30 . 
Bu görsel dilin kozmik merkez kavramı ile de temellendirildiği fark edilir. Zira kompozisyonda, bir merkez sembolü olan sarayın içerisinde, kendisi de bir merkez olarak yer alan sultanın, kompozisyonun tam orta ekseninden geçen dikey aks üzerinde, her biri birer merkez ve iktidar sembolü olan unsurlarla birlikte yer almış olması, bahsetmiş olduğumuz kozmik merkez üzerinden hareket eden kurguyu gözler önüne serer. Bu dikey aks, üzerinde yer alan diğer unsurlarla birlikte evrenin merkezinde, yeri ve gögü birleştirdiğine inanılan “Kutup Yıldızı”na denk düşmüş olması ile sultanın dünyanın merkezinde yeri ve göğü birleştiren bir gök direği (Kutup Yıldızı) oluşuna atıf yapıyor gibi görünmektedir.

Türklerde yeri ve göğü birleştiren bir Kutup Yıldızı olması hasebi ile hükümdarın barındırdığı ikili iktidar, incelemiş olduğumuz minyatürde yeri ve göğü, dünya ile ukbâyı birleștiren halife-sultan imgesi ile de birlikte ilerler. Zira bu minyatürde hilafet makamının da sahibi olan Kanunî Sultan Süleyman'ın, yeri ve göğü, dünya ile ukbâyı birleştiren bir halife-sultan imgesi olarak resmedilmiş olduğu fark edilir.

Tüm bu veriler mevcut minyatürde kozmik kurgu ve kozmik merkez üzerinden yol alan bu iktidar dilinin nakkaş tarafından bilinçli bir şekilde inşa edilmiş olabileceği ihtimalini akla getirir. Bu dilin Osmanlı padişahları arasında en güçlü iktidar figürlerinden biri olan Kanunî Sultan Süleyman'ın saltanat yıllarını konu edinen ve onun himayesinde yazılmış bir resimli tarih kitabı olan Süleymannâme içerisinde yer almış olması oldukça önemlidir. Zira daha önce de belirtmiş olduğumuz gibi Süleymannâme Osmanlılardaki ilk resimli tarih kitabı olup, bu eserde yer alan minyatürler Osmanlı klâsik minyatür üslubunun ana kompozisyon şemalarını tesis etmiştir. Bu durum, Türk kozmoloji düşüncesi üzerinden temellenen bir iktidar dilinin sonraki dönem Osmanlı minyatürlerinde de kullanılmış olabileceği fikrini akla getirir. Osmanlı minyatürlerinde Türk kozmoloji düşüncesi üzerinden yol alan bir iktidar dilinin var olabileceğine işaret etmesi açısından bir başlangıç adımı olarak düşünülebilecek bu makalenin bu alanda yapılacak olan yeni çalışmalara katkı sağlayacağı ümit edilmektedir. 


\section{Kaynakça}

Akalay, Zeren, “Tarihi Konularda Türk Minyatürleri”, Sanat Tarihi Yllll$\breve{g l}$ 1969-1970, İstanbul, İstanbul Üniversitesi Edebiyat Fakültesi Sanat Tarihi Enstitüsü, 1970.

Akın, Günkut, “Edirne Selimiye Camii’ndeki Müezzin Mahfili Üzerine Düşünceler", Uluslararası Mimar Sinan Sempozyumu Bildirileri (Ankara, 24-27 Ekim 1988), Ankara, Türk Tarih Kurumu Basımevi, 1996.

, "The Muezzin Mahfili and Pool of the Selimiye Mosque in Edirne”, Muqarnas, volume 12, 1995.

Alizade, Rövşen, Türk Halk Kültürü ve Tarihi, İstanbul, Karma Kitaplar, 2014.

Arslan, Ali, Türk Tarihinde Lider ve Liderlik Anlayışı, İstanbul, Kitabevi, 2014.

Asan, Unal, Anıt Ağac Kavramının Fiziksel, Görsel ve Sosyokültürel Dayanakları, İstanbul, Arkeoloji ve Sanat Yayınları, 2016.

Atasoy, Nurhan, "1558 tarihli Süleymannâme ve Macar Nakkaş Pervane", Sanat Tarihi Yıllığ $1969-1970$, İstanbul, İstanbul Üniversitesi Edebiyat Fakültesi Sanat Tarihi Enstitüsü, 1970.

Atıl, Esin, “Arifî'nin Süleymannâmesi'nde Kanunî’nin Seferleri”, P Dünya Sanatı Dergisi, sa. 30, İstanbul 2003.

, Süleymannâme The Illustrated History of Süleyman the Magnificent, New York, Harry and Abrams Inc., 1986.

Aykut, Muhittin, “Türk Mimarlığında Su Kompozisyonları Kullanımı”, 8. Uluslararası Türk Sanatları Kongresi Bildiriler (23-27 Eylül 1991 İstanbul), c. 1, Ankara, T. C. Kültür Bakanlığı Yayınları, 1995.

Bağcı, Serpil - Çağman, Filiz - Renda, Günsel - Tanındı, Zeren, Osmanlı Resim Sanatı, İstanbul, T. C. Kültür ve Turizm Bakanlığı, 2006.

Balc1, Cengiz, Destanlar, Kitabeler ve Kutadgu-Bilig'den Örneklemelerle Türk Devlet Töresi, İstanbul, Bilgeoğuz, 2018.

Barthold, Vasilij Vladimiroviç, İslâm'da İktidarın Serüveni Halife ve Sultan, İstanbul, Yeditepe, 2012.

Bayat, Fuzuli, Türk Mitolojik Sistemi 1, İstanbul, Ötüken, 2015. , Türk Mitolojik Sistemi 2, İstanbul, Ötüken, 2015. 
Bruckhardt, Titus, Doğu'da ve Batı'da Kutsal Sanat, İstanbul, İnsan, 2017.

Cimilli, H. Canan, “Topkapı Sarayı'nın Anıtsal Tören Kapılarındaki Simgesellik, Kapı Kavramı ve Törenler ile Bağlantısı”, Filiz Çağman'a Armağan, İstanbul, Lale Yayınc1lık, 2018.

Çağman, Filiz, "Osmanlı Sarayının Yorumu: Üstad Osman ve Dizisi”, Padişahın Portresi Tesavir-i Âl-i Osman, İstanbul, Türkiye İş Bankası, 2000.

Çaycı, Ahmet, İslam Mimarisinde Anlam ve Sembol, Konya, Palet Yayınları, 2017.

, Selçuklularda Egemenlik Sembolleri, İstanbul, İz Yayıncılık, 2008.

Değirmenci, Tülin, İktidar Oyunları ve Resimli Kitaplar II. Osman Devrinde Değişen Güç Simgeleri, İstanbul, Kitap Yayınevi, 2012.

Durbilmez, Bayram, Türk Dünyası Kültürü, İstanbul, Ötüken, 2017.

Eliade, Mircea, "Su ve Su Simgeleri”, Z Kültür ve Sanat, sa. 2, İstanbul, Zeytinburnu Belediyesi, 2017.

Erdoğan Peçe, Zaliha, “Nakkaş Osman'ın Padişah Portrelerinde Görülen Kozmik Kurgu ve İktidarı Taltif Edici Unsurlar, Levnî’nin Bu Kalıba Getirmiş Olduğu Yenilikler”, Lale Kültür Sanat ve Medeniyet Dergisi, sa. 2, İstanbul, 2020.

Ergun, Pervin, Türk Kültüründe Ağaç Kültü, Ankara, Atatürk Kültür Merkezi Başkanlığı, 2017.

Fetvac1, Emine, Sarayın İmgeleri, İstanbul, Yapı Kredi Yayınları, 2013.

Genç, Reşat, Türk Inanışları ile Milli Geleneklerinde Renkler ve Sarı Kırmızı Yeşil, Ankara, Atatürk Kültür Merkezi, 2009.

Gökbilgin, Tayyib, Kanunî Sultan Süleyman, İstanbul, Kronik, 2019.

Güler, Turgut, Demir Kuşaklı Cihângir Süleymannâme, İstanbul, Ötüken, 2016.

Gültepe, Necati, Türk Mitolojisi, İstanbul, Kap1, 2017.

Günay, Reha, "Süleymannâme Minyatürlerinde Mekân ve Anlatım Teknikleri“, Topkapı Sarayı Müzesi Yıllık 5, İstanbul, 1992.

Harmankaya Akçı1, N. Çiçek, Mimar Sinan Camilerinde Sembolizm, İstanbul, Kitabevi, 2018.

İnalcık, Halil, Osmanlı'da Devlet, Hukuk ve Adâlet, İstanbul, Kronik, 2017.

Kafesoğlu, İbrahim, Türk Milli Kültürü, İstanbul, Ötüken, 2017. 
Koca, Salim, “ Türkiye Selçuklu Devleti Hükümdarlarının Aldıkları ve Kullanılan Hâkimiyet ve Hükümdarlık Sembolleri”, III. Milli Selçuklu Kültürü ve Medeniyeti Semineri Bildirileri 20-22 Mayıs, Konya, Selçuk Üniversitesi Yayınlar1, 1994.

Küçük Tursun, Fatmagül, “Türk Atasözlerinde Renkler”, Renk Kitabı, İstanbul, Kitabevi, 2017.

Küçükaşc1, Mustafa Sabri, “Topkapı Sarayı'nda Kutsiyet ve Kutsal Mekânlar”, Topkapı Sarayı'nı Anlatmak, İstanbul, Kültür ve Turizm Bakanlığı, 2018.

Lewis, Bernard, İslam 'in Siyasal Söylemi, Ankara, Phoenix, 2007.

Mahir, Banu, Osmanlı Minyatür Sanatı, İstanbul, Kabalc1, 2012.

Memiş, Ekrem, Türk Kültür Tarihi (Türk Kültüründen Bazı Kesitler), Bursa, Ekin, 2015.

Merçil, Erdoğan, Selçuklular'da Hükümdarlık Alâmetleri, Ankara, Türk Tarih Kurumu, 2007.

Necipoğlu, Gülru, 15. ve 16. Yüzyılda Topkapı Sarayı Mimarî, Tören ve İktidar, İstanbul, Yapı Kredi Yayınları, 2014.

Niyazi, Mehmed, Türk Devlet Felsefesi, İstanbul, Ötüken, 2017

Ögel, Bahaeddin, Türk Kültür Tarihine Giriş: Türklerde Tuğ ve Bayrak (Hunlardan Osmanlılara), c. 6, Ankara, Kültür Bakanlığı, 1989.

, Türk Mitolojisi, c. 1, Ankara, Türk Tarih Kurumu, 2014.

, Türk Mitolojisi, c. 2, Ankara, Türk Tarih Kurumu, 2014.

, Türklerde Devlet Anlayışı, İstanbul, Ötüken, 2016.

Ögel, Semra, Anadolu'nun Selçuklu Çehresi, İstanbul, Akbank, 1994.

Özer Pınarbaşı, Simge, "Taht Tiplerinin Oluşmasında İnançların Etkisi”, Sanat ve İnanç 1, Rıfkı Melûl Meriç Anısına, İstanbul, Mimar Sinan Güzel Sanatlar Üniversitesi Tük Sanat Tarihi Uygulama ve Araştırma Merkezi, 2004.

, Çağlar Boyu Tahtın Simgesel Anlamları Işı̆̆ında Türk Tahtları, Ankara, T. C. Kültür ve Turizm Bakanlığı Yayınları, 2004.

Öztabak, Murat, “Âb-1 hayat”, Z Kültür Sanat Şehir, sa. 2, İstanbul, Zeytinburnu Belediyesi, 2017.

Öztuna, Y1lmaz, Kanunî Sultan Süleyman, İstanbul, Ötüken, 2016.

Peçe, Zaliha, "Nakkaş Osman ve Levnî”ye Ait Padişah Portrelerinin Kompozisyon ve Teknik Açıdan Karşılaştırılması”, (Yayımlanmamış Yüksek Lisans 
Tezi), Fatih Sultan Mehmet Vakıf Üniversitesi Güzel Sanatlar Enstitüsü Geleneksel Türk Sanatları Anasanat Dalı, İstanbul, 2015.

Şahin, Kaya, Kanunî Devrinde Imparatorluk ve İktidar Celalzâde Mustafa ve 16. Yüzyıl Osmanlı Dünyası, İstanbul, Yapı Kredi Yayınları, 2014.

Taş, İsmail, Türk Düşüncesinde Kozmogeni Kozmoloji, Konya, Kömen, 2011.

Taşpınar, İsmail, "Halk İnançlarında Su”, Z Kültür ve Sanat, sa. 2, İstanbul, Zeytinburnu Belediyesi, 2017.

, “Su, Dinler ve Ritüeller", $Z$ Kültür ve Sanat, sa. 2, İstanbul, Zeytinburnu Belediyesi, 2017.

Tekin, Talat (haz.), Orhon Yazıtları, Kül Tigin, Bilge Kăgan, Tunyukuk, Ankara, BilgeSu, 2017.

Turan, Namık Sinan, Hilâfet Erken İslâm Tarihinden Osmanlı'nın Son Yüzyllına, İstanbul, İstanbul Bilgi Üniversitesi Yayınları, 2017.

Uzunçarşı11, İsmail Hakkı, Osmanlı Tarihi, İstanbul'un Fethinden Kanunî Sultan Süleyman'ın Ölümüne Kadar, c. 2, Ankara, Türk Tarih Kurumu, 2016.

Vives, Fatma Sinem Ery1lmaz Arenas, "The Shehcis of Sultan Süleyman: Arif and Eflatun and Their Dynastic Project", (Sanal Ortamda Ulaşıma Açık Doktora Tezi), The University of Chicago, Chicago, 2010.

Von Gabain, Annemarie, "Renklerin Sembolik Anlamları", Türkoloji Dergisi, c. 3,1968 . 